\title{
ETHNIC INEQUALITY AND THE DISMANTLING OF DEMOCRACY A Global Analysis
}

\author{
By CHRISTIAN HOULE*
}

A society, therefore, which is ridden by a dozen oppositions along lines running in every direction may actually be in less danger of being torn with violence or falling to pieces than one split along just one line. For each new cleavage contributes to narrow the cross clefts, so that one might say that society is sewn together by its inner conflict.

$\mathrm{D}$ OES inequality between ethnic groups destabilize democracies? The literature on democracy has witnessed a proliferation of studies about the relationship between economic inequality and political regimes, with most authors agreeing that inequality harms the consolidation of democracy. ${ }^{1}$ Yet this literature typically focuses on the overall level of inequality in a society, leaving unanswered questions about the effect of inequality between ethnic groups on the dismantling of democracy. Meanwhile, an important literature has emerged that ex-

\footnotetext{
* Winner of the 2014 Best Paper Award in comparative democratization presented at the American Political Science Association annual meeting, and of the $2012 \mathrm{Kellogg} /$ Notre Dame Award for the best paper in comparative politics presented at the Midwest Political Science Association annual meeting. Earlier versions of this article were presented at Michigan State University, the Ohio State University, Florida State University, Arizona State University, the University of Montreal, Trinity College, Dublin, the Dublin City University, and the European Political Science Association. I gratefully acknowledge comments and suggestions from Chang Alex, Kenneth Benoit, William D. Berry, Cristina Bodea, Michael Bratton, Eric Chang, Jeffrey Conroy-Krutz, Alexandre Debs, Stanley Engerman, Mark Fey, Michael Gallagher, Guy Grossman, Gretchen Helmke, Timothy Hicks, John Huber, Koji Kagotani, Mark A. Kayser, Patrick Kuhn, G. Bingham Powell, Clionadh Raleigh, Ani Sarkissian, Randall Stone, Gunes Tezcur, Jeffrey Weber, and Dwayne Woods. Special thanks to Elizabeth Lane, Chunho Park, and Fangjin Ye for their outstanding research assistance; Carolyn Logan for giving me access to forthcoming Afrobarometer surveys on Burundi and Niger; and Philip Roessler for sharing data on the ethnicity of coup and rebellion leaders. All errors are mine.

** Alsworth in The Principles of Sociology, pp. 164-65.

${ }^{1}$ For example, Boix 2003; Haggard and Kaufman 2012; Houle 2009; Houle forthcoming; Muller 1988.
}

World Politics 67, no. 3 (July 2015), 469-505

Copyright (C) 2015 Trustees of Princeton University

doi: 10.1017/S0043887115000106 
amines the effect of horizontal inequality - that is, inequality between culturally defined groups - on civil conflicts. ${ }^{2}$ These authors argue and empirically demonstrate that horizontal inequality increases the likelihood that a country experiences a civil war. Surprisingly, these literatures have largely developed independently of one another. Despite being shown to play a key role in civil conflicts, the effect of inequality between ethnic groups on the dismantling of democracy has yet to be analyzed theoretically and tested empirically within a cross-national setting.

The lack of attention given to the effect of inequality between ethnic or religious groups is especially puzzling in light of the central role played by the structure of social cleavages in pioneering theories of democratic stability. ${ }^{3}$ These authors argue that reinforcing cleavages destabilize democracies, whereas crosscutting cleavages-meaning that, for example, ethnic groups are themselves broken down by other cleavages-promote the consolidation of democracy by weakening the destabilizing effect of any single cleavage. Reinforcing cleavages are claimed to accentuate in-group loyalties, enabling groups to mount challenges against democratic regimes. Moreover, coinciding cleavages tend to create stable electoral majorities, rendering smaller groups unlikely to respect the democratic process. ${ }^{4}$ These arguments are supported by multiple case studies. ${ }^{5}$

This article fills this gap by analyzing and testing the effect of inequality between and within ethnic groups on the dismantling of democracy. I argue that between-ethnic-group inequality (BGI) - or horizontal inequality - destabilizes democratic regimes, but that its effect is strongest when within-ethnic-group inequality (WGI) is low. Under conditions of high BGI and low WGI, ethnic and class cleavages reinforce each other. I theorize that when WGI is low, BGI destabilizes democracy by accentuating conflicts over distribution/redistribution and by increasing the political salience of ethnicity.

First, as BGI increases, the gap between the preferences of different groups for different economic policies widens, inciting them to impose their preferred policy through an autocracy. The effect of BGI is

\footnotetext{
${ }^{2}$ For example, see Cederman, Weidmann, and Gleditsch 2011; Esteban and Ray 2011; Gubler and Selway 2012; Østby, Nordås, and Rød. 2009; Østby 2008; Stewart 2000; Stewart 2002; Stewart 2008.

${ }^{3}$ See, for example, Dahl 1956; Dahl 1971; Diamond 1988; Dunning and Harrison 2010; Lipset 1960; Lipset and Rokkan 1967; Rae and Taylor 1970; Ross 1920; Simmel 1908; Truman 1951; Verba 1965.

${ }^{4}$ Chandra 2005.

${ }^{5}$ For example, see Diamond 1988 on Nigeria; Rokkan 1967 on Norway; Lin and Zhang 1998 on Taiwan.
} 
strongest when WGI is low because different members of each group share similar economic preferences, enabling them to agree on postdemocracy policies. When WGI is sufficiently high, however, increasing BGI does not undermine democracy because members of the same groups have very different policy preferences. Second, high levels of BGI combined with low levels of WGI strengthen in-group loyalties by creating clear demarcations between members of different groups, thus reinforcing the political salience of ethnicity, which in turn magnifies the inherent dangers of ethnicity for democracy.

Using survey data from Demographic and Health Surveys (DHS), Afrobarometer, World Values Survey (wvs), Latinobarometer, International Social Survey Program (ISSP), and Comparative Study of the Electoral Systems (CSES), I construct a data set on inequality between and within ethnic groups. The data set covers more than seventy-one democracies and 241 ethnic groups worldwide between 1960 and 2007. Only eight ethnically heterogeneous countries that have been democratic during at least one year in the period covered are omitted from the analysis because of a lack of data on BGI/WGI. ${ }^{6}$ Using group- and country-level analyses, I conduct the first cross-national test to date of the effect of ethnic inequality on transitions away from democracy. The results provide support for my hypothesis: when WGI is low, BGI harms democracy, but when WGI is high, BGI has no discernable effect.

\section{Ethnic Inequality and Democratic Consolidation}

Although there are still controversies about the relationship between inequality and the likelihood of a state becoming a democracy, most scholars agree that inequality destabilizes already established democracies. ${ }^{7}$ Inequality is thought to increase the likelihood of democratic breakdowns notably because it increases the incentives of different social classes to control the regime in order to impose their preferred economic policies. ${ }^{8}$ When applied to the question of redistribution in democracies, the median-voter theorem suggests that relatively unequal democracies should redistribute more from the rich toward the poor than democracies that are more equal. ${ }^{9}$ Inequality increases the incentives of rich groups to overthrow the regime and install an autocracy.

\footnotetext{
${ }^{6}$ These are the Dominican Republic, France, the Gambia, Guinea-Bissau, Israel, Lebanon, Mongolia, and Myanmar.

${ }_{7}^{7}$ For example, Boix 2003; Haggard and Kaufman 2012; Houle 2009, Houle forthcoming; Muller 1988.

${ }^{8}$ Acemoğlu and Robinson 2006; Boix 2003; Dahl 1971.

${ }^{9}$ Meltzer and Richard 1981.
} 
There is also a substantial literature that relates ethnic diversity to instability in democracies. ${ }^{10}$ Because ethnicity is largely, though not fully, ascriptive and unchangeable, it may lead to more serious conflicts than cleavages that are more fluid, such as those based on social class. ${ }^{11}$ Indeed, case studies point to ethnicity as a major source of unrest.

Considering these literatures together raises a question about what the effect of inequality between and within ethnic groups is on the consolidation of democracies. I address this question by first looking at a related literature on the effect of ethnic inequality on civil wars. ${ }^{12}$ While this literature largely agrees that BGI induces conflict, it is much more divided on the effect of WGI.

One group of authors argues that the positive effect of BGI on conflict becomes more pronounced as WGI increases. ${ }^{13}$ This makes sense, as war requires manpower and financial resources. A high level of withingroup inequality means that there is a large group of poor people with low opportunity costs who are willing to fight for small financial compensation, and a group of rich people who are able to finance the conflict. Within-group inequality is thus argued to enhance the capacity of a group to finance a full-scale war.

The logic of this argument cannot be easily extended to transitions away from democracy. This is mainly because, although some democratic breakdowns take the form of civil wars, the vast majority of them are caused by military or executive coups. Many transitions occurr in the midst of war but in the end it was a coup that directly caused the demise of the regime, for example, in Uganda in 1985. In fact, democratic breakdowns are usually modeled as coups in the game theory literature. ${ }^{14}$

Contrary to wars, coups do not necessitate large fighting forces and significant financial resources because they rarely involve prolonged fighting. ${ }^{15}$ In addition, this argument cannot be easily extended to small-scale political disorder that falls short of civil war, which often indirectly contributes to the undoing of democracy. ${ }^{16}$ In short, democratic reversals are almost always inexpensive in both manpower and financial resources.

${ }^{10}$ For example, Dahl 1971; Rabushka and Shepsle 1972.

${ }^{11}$ Horowitz 1985.

${ }^{12}$ Cederman, Weidmann, and Gleditsch 2011; Esteban and Ray 2011; Gubler and Selway 2012;

Kuhn and Weidmann 2014; Østby, Nordås, and Rød 2009; Østby 2008; Stewart 2000; Stewart 2002; Stewart 2008.

${ }^{13}$ For example, Esteban and Ray 2011; Gates 2002; Kuhn and Weidmann 2014.

${ }^{14}$ See Acemoğlu and Robinson 2006; Boix 2003; Dunning 2008.

${ }^{15}$ Collier and Hoeffler 2005.

${ }^{16}$ See Diamond 1988; Lipset 1960. 
A second group of scholars draws on the literature on coinciding and crosscutting cleavages and instead contends that WGI weakens the effect of BGI on civil war, notably because it reduces within-group cohesion. ${ }^{17}$ These arguments have been applied to cleavages beyond class and ethnicity. For example, using a similar logic, Lars-Erik Cederman, Jan Ketil Rød, and Nils Weidmann have shown that conflicts are more likely when ethnicity and geography reinforce each other, and Jeffrey Seul and Joel Sawat Selway have shown that conflicts are more likely when ethnicity and religion reinforce each other. ${ }^{18}$

Below, I suggest that the arguments of this second school of thought can be applied to transitions away from democracy, and hence that the destabilizing effect of BGI on democracy weakens as WGI increases. In fact, most scholars studying democratic consolidation, small-scale instability (rather than civil war), or ethnic voting espouse this view. ${ }^{19}$ Building on this rich literature, I theorize that when WGI is low, BGI destabilizes democracy by generating conflicts over the distribution of wealth or income, and by reinforcing the salience of ethnicity.

\section{Between-Group Inequality Creates Distributional Conflict}

As discussed above, some scholars argue that inequality between social classes harms democracy by stirring distributive conflict. ${ }^{20} \mathrm{I}$ extend this argument to a case in which the population is divided along both class and ethnic lines. This first mechanism focuses on the effect of inequality on democratic consolidation and suggests that inequality becomes more harmful when it is reinforced by ethnicity.

Imagine a democracy in which there are two or more ethnic groups and assume that political leaders tend to adopt the policies, including redistributive and economic policies, preferred by members of their own groups. ${ }^{21}$ These policies need not be restricted to income taxation and redistribution. One potential source of contention, for example, can be the working language of the government, which has distributive implications through access to bureaucratic jobs. ${ }^{22}$ Further assume that a subgroup of an ethnic group, usually its elites, can initiate a transition

\footnotetext{
${ }^{17}$ See Gubler and Selway 2012; Horowitz 1985; Sambanis and Milanovic 2011; Stewart 2000. Both arguments remain largely untested because of data limitations. See Kuhn and Weidmann 2014, however, for a recent empirical analysis finding support for the first view.

${ }^{18}$ Cederman, Rød, and Weidmann 2006; Seul 1999; Selway 2011.

${ }^{19}$ For example, see Dahl 1956; Dahl 1971; Diamond 1988; Dunning and Harrison 2010; Lin and Zhang 1998; Lipset 1960; Lipset and Rokkan 1967; Truman 1951.

${ }^{20}$ For example, Acemoğlu and Robinson 2006; Boix 2003.

${ }^{21}$ Franck and Rainer 2012, for example, find that in sub-Saharan Africa there is strong evidence that political leaders tend to favor members of their own group, even in democracies.

${ }^{22}$ Selway 2011.
} 
to autocracy at a certain cost, $\mathrm{C}>0$. After a successful coup, coup leaders, who form the new ruling elite, have to adopt a new set of economic policies that will guarantee the support of the remaining members of their ethnic group. The ruling elite does this by adopting policy that is a combination of the preferred policies of the different members of the group.

Between-group inequality widens the gap between the economic preferences of the different groups, increasing the incentives of any given group to depose the regime and adopt its own preferred policies. A group that is poor, for example, would want to control policies in order to adopt a high level of redistribution and other poor-friendly policies, while a rich group would want to do the opposite. ${ }^{23}$

The magnitude of the effect of BGI depends on the level of WGI, which, for simplicity, can be conceived as inequality between the elite of a group, who are assumed to carry out the coup, and its other members. The higher the WGI, the greater the difference between the preferences of the elite and nonelite in the group, and thus the farther from their own preferences is the policy that must be adopted by the former to gain the support of the latter. Within-group inequality thus lowers the benefits of taking power for any potential coup leaders, therefore reducing, for any fixed $\mathrm{C}$, the likelihood that a coup will be staged in the first place.

But why is inequality more destabilizing when it is reinforced by ethnicity? One could imagine, for example, that inequality between and within alternative (that is, nonethnic) types of groups, such as social classes, could have the same implications for democracy. Ethnicity magnifies the destabilizing effect of inequality because it lowers the cost of staging a coup (C) and decreases the cost associated with establishing and maintaining a new regime. For one thing, ethnicity provides political entrepreneurs with dense social networks and other tools, such as a shared language, that can be used to reach and mobilize potential supporters. ${ }^{24}$

\footnotetext{
${ }^{23}$ One could argue that rich groups should be more likely to initiate breakdowns since democracy ensures that at least some redistribution takes place. However, the empirical literature has demonstrated that democracy does not necessarily increase redistribution or reduce inequality (for example, Timmons 2010; Slater, Smith, and Nair 2014). Moreover, authoritarian regimes are often neopatrimonial regimes, in which the rulers maintain power by providing material benefits to a coalition that is often based on ethnicity (see, for example, Bratton and van de Walle 1997). Poorer members of a group may benefit more from redistribution in autocracies dominated by their group-which controls patronage networks - than in democracies not controlled by their group. The empirical analysis presented below, however, does find that rich groups are more likely to instigate transitions to autocracy.

${ }^{24}$ Gubler and Selway 2012; Selway 2011.
} 
Ethnicity also reduces the ex ante uncertainty associated with staging a coup and founding a new regime, effectively reducing the costs of doing so. Due to its ascriptive and sticky nature, ${ }^{25}$ ethnicity provides an easily identifiable and stable source of political support on which coup leaders can rely. When most people support leaders from their own group, coethnics have few exit options short of supporting another ruler from their group. Rulers thus have incentives to target only their coethnics when, for example, distributing benefits and services, which creates a stable equilibrium. Class affiliations, however, are much more fluid, meaning that supporters are harder to identify and more likely to switch their allegiance. In other words, inequality between ethnic groups is more destabilizing than inequality between social classes.

\section{Between-Group Inequality Increases the Salience OF ETHNICITY}

Between-group inequality, when combined with low levels of wGI, increases the salience of ethnicity, which in turn harms democratic consolidation. I argued above that ethnicity makes inequality more destabilizing. In this section I argue that inequality — when it falls along ethnic lines-enhances the dangers to democracy inherent to ethnicity. A combination of high BGI and low WGI levels creates clear demarcations between groups, increasing in-group loyalties, for example, through a shared history of grievance. ${ }^{26}$ Individuals are more likely to relate to other members of their ethnic group if they share the same living conditions (low WGI), and live under very different conditions than members of other groups (high BGI).

Figure 1 illustrates my argument by showing how WGI affects withingroup identification. It gives the mean income of groups $\mathrm{A}$ and $\mathrm{B}$, as well as standard deviations around the mean of each distribution. Groups with wider standard deviations have higher levels of WGI. Betweengroup inequality is kept constant across cases (A and B are fixed). In case 1, WGI is low for both groups, and thus I expect within-group loyalty to be strong. Case 2 illustrates a situation in which WGI is high for both groups. Within-group loyalty should be particularly weak because of the large overlap between the two distributions.

This argument builds on earlier work on the structure of social cleavages, according to which individuals' loyalty to other members of their group along a particular cleavage (for example, ethnicity, class, religion,

${ }^{25}$ Horowitz 1985; Selway 2011.

${ }^{26}$ Gubler and Selway 2012; Selway 2011; Stewart 2000. 
Case 1: Low WGI in groups $A$ and $B$, high within-group loyalty

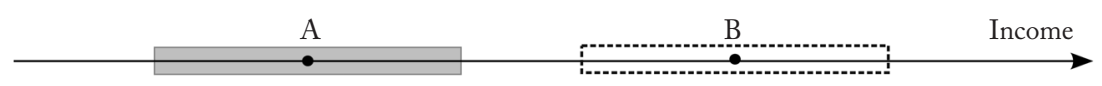

Case 2: High WGI in groups A and B, low within-group loyalty

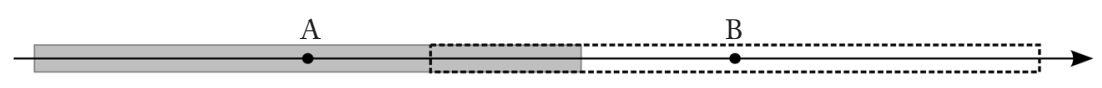

Case 3: Low WGI in group A and high WGI in group B, intermediate within-group loyalty for both groups

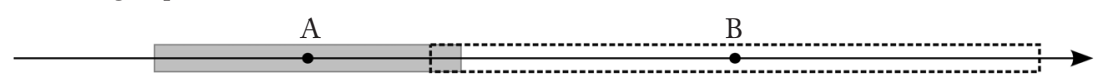

Std. around mean of group A i S Std. around mean of group B B

FIGURE 1

EfFect of WGI on Within-Group Loyalty Keeping BGI Constant ${ }^{a}$

\begin{abstract}
${ }^{\mathrm{a}} \mathrm{A}$ and $\mathrm{B}$ give the mean income of groups $\mathrm{A}$ and $\mathrm{B}$, respectively. The boxes show the standard deviations around each mean. In case 1 WGI for both groups is low and within-group loyalty is expected to be strong. Case 2 refers to a situation in which WGI for both groups is high and so within-group loyalty is weak. In case 3, WGI of group A is low (as in case 1) but that of group B is high (as in case 2). Within-group loyalty is expected to be weaker than in case 1 but stronger than in case 2 for both groups.
\end{abstract}

urban/rural location, or geography) strengthens when they find themselves in the same group along other cleavages. ${ }^{27}$ For example, if an individual shares the same religious affiliation as members of other ethnic groups, that person will be more likely to engage in social contact with them and less likely to self-perceive as fundamentally different from them. Many scholars have applied this argument more specifically to ethnicity rather than to social cleavages in general, and argue that ethnicity becomes more salient when it is reinforced by other cleavages. ${ }^{28}$ For example, experimental data from Thad Dunning and Lauren Harrison demonstrate that crosscutting ties reduce voting along ethnic lines in Mali. ${ }^{29}$

Ethnicity becomes more dangerous to democracy as its salience increases. ${ }^{30}$ In fact, most quantitative studies find that the mere existence of ethnic divisions does not induce democratic breakdowns. ${ }^{31}$ Imag-

${ }^{27}$ See, for example, Lipset 1960; Rae and Taylor 1970; Ross 1920; Simmel 1908.

${ }^{28}$ For example, Chandra 2005; Diamond 1988; Laitin 1986; Lipset 1960; Selway 2011.

${ }^{29}$ Dunning and Harrison 2010.

${ }^{30}$ Chandra 2005; Diamond 1988; Laitin 1986; Lipset 1960; Rabushka and Shepsle 1972. Cederman, Wimmer, and Min 2010 find that ethnicity only increases the probability of civil war when it is politically salient.

${ }^{31}$ For example, Houle 2009; Papaionannou and Siourounis 2008. 
ine two democracies with similar levels of ethnic diversity: $\mathrm{S}$, in which ethnicity is highly salient, and NS, in which ethnicity is not as salient. A subgroup from a given ethnic group can overthrow a democracy, for example, to set policies or gain access to spoils. ${ }^{32}$

Political entrepreneurs from democracy $S$ face a lower cost of staging a coup and can more easily establish and maintain the new regime than those from NS. As argued above, the ascriptive and sticky nature of ethnicity means that political entrepreneurs from $\mathrm{S}$ have a ready-made group of supporters that can be reached through existing social networks and that are unlikely to withdraw their support. Potential coup leaders from NS, however, are not sure that their coethnics will support them during and after a coup, rendering them less likely to stage one.

Moreover, as ethnicity's salience increases, elections become increasingly determined by demographics, which decreases the incentives of smaller groups to comply with the rules of the democratic game. ${ }^{33}$ As Adam Przeworski argues, ex ante uncertainty over the electoral process is an essential component of any well-functioning democracy. ${ }^{34}$ Such situations can lead to an environment of significant political tensions (that may or may not rise to the level of civil war), which in turn can harm democratic consolidation. ${ }^{35}$ In fact, political disorder often creates incentives and opportunities for members of groups other than those directly in conflict with the government, including those that are politically dominant, to usurp power. The example of Guatemala in 1982, discussed below in the section on country examples, illustrates this premise.

As suggested by this last point, the logic of my argument, in principle does not preclude members of ethnic groups that are already politically dominant from overthrowing a democracy. Ethnic inequality could influence members of a dominant group to stage a military or executive coup, for example, if they believe they may lose an election or if they want to enhance their dominance. Carrying out a successful coup usually requires some access to power, meaning that members of dominant groups have an advantage in that regard. ${ }^{36}$ Therefore, the analysis

\footnotetext{
${ }^{32}$ Political entrepreneurs relying on ethnicity and their supporters are assumed to have goals similar to those relying on other cleavages; the groups often compete over power, resources, and policy influence rather than cultural values. See Cohen 1969; Diamond 1988. However, my argument does not depend on this assumption. If groups were instead motivated by cultural values we should also expect them to become more likely, for example, to want to impose their culture through an autocracy as ethnicity becomes more salient.

${ }^{33}$ Chandra 2005.

${ }^{34}$ Przeworski 1991.

${ }^{35}$ Diamond 1988; Lipset 1960.

${ }^{36}$ Roessler 2011.
} 
develops two sets of BGI/WGI indicators: one that measures inequality between each ethnic group (including those that are dominant) and the country's average, and one that measures inequality between politically excluded groups and those that are dominant.

Furthermore, my argument implies not only that groups with high BGI and low WGI are more likely to initiate breakdowns, but also that democracies with high BGI and low WGI across all groups should be more unstable. This is illustrated in Figure 1, case 3, in which group B has a large WGI and group A has a low one. My argument suggests that in this case, within-group loyalty should be weaker than in case 1 but stronger than in case 2 for both groups (although within-group loyalty should be stronger for $\mathrm{A}$ than $\mathrm{B}$ ). In case 3, the overlap between the two distributions is larger than in case 1 but smaller than in case 2. Even for group A, the fact that many members of group B share a similar income level decreases within-group identification relative to case 1 . I thus conduct empirical tests both at the group and country levels.

\section{DATA}

The main sample consists of seventy-one countries that have been democratic during at least one year between 1960 and 2007. Four additional countries are included in the supplementary material, in Table A14, which uses an alternative indicator of democracy. ${ }^{37}$ In Figure 2, the countries that are included in the sample are in gray. Countries in white are not included either because they were nondemocratic during the full period covered (for example, China) or because they were coded as ethnically homogeneous (for example, Denmark) in the Ethnic Power Relations (EPR) data set, on which I rely to identify ethnic groups. ${ }^{38}$ By definition, one cannot study democratic consolidation in countries that have never been democratic. Similarly, one cannot calculate inequality between ethnic groups in countries that do not have multiple ethnic groups.

Only eight ethnically diverse democracies (in black) — the Dominican Republic, France, the Gambia, Guinea-Bissau, Israel, Lebanon, Mongolia, and Myanmar - are excluded because of the lack of data on BGI and WGI. Figure 2 shows that more than 90 percent of all ethnically heterogeneous democracies are included in the data set. All countries

\footnotetext{
${ }^{37}$ These countries are Belarus, Mozambique, Russia, and South Africa; Houle 2015.

${ }^{38}$ Wimmer, Cederman \& Min 2009.
} 


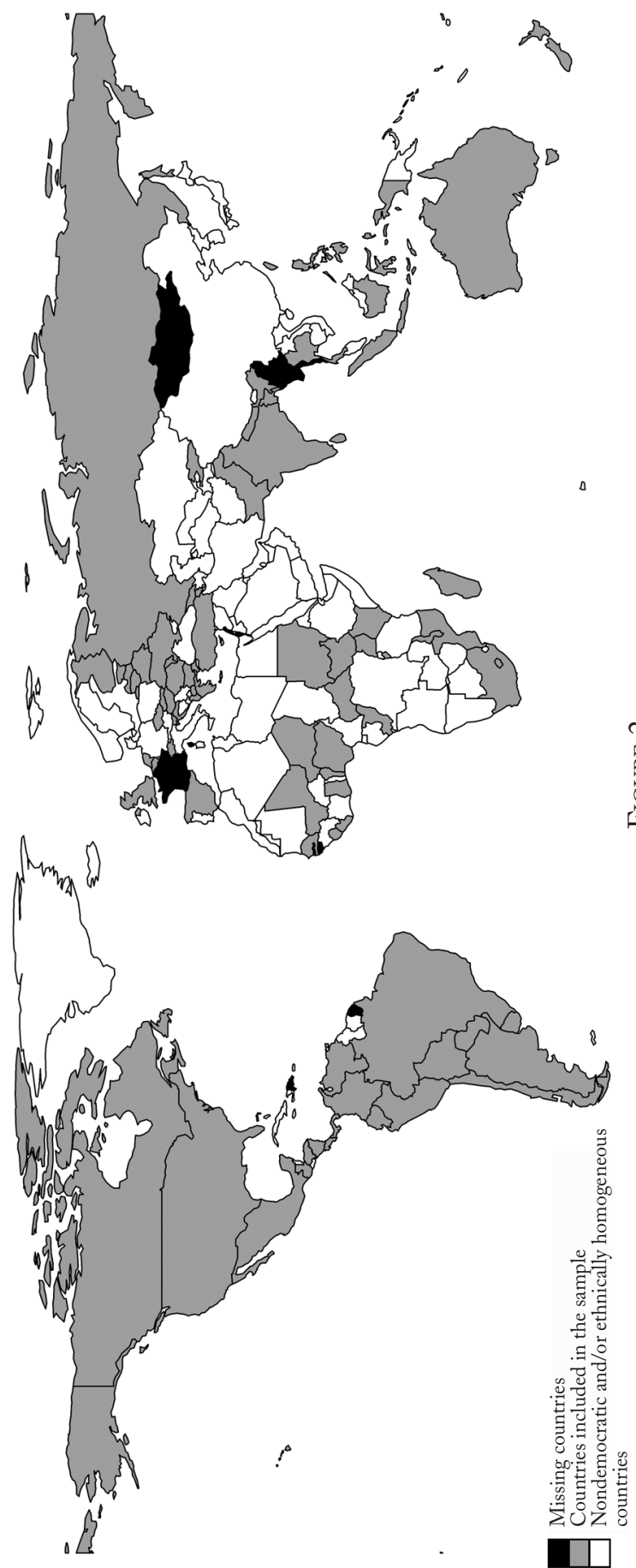

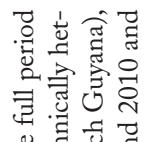

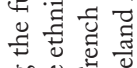
. 吾氜 焉

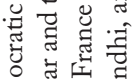

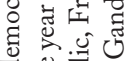

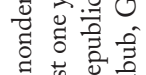
范芯芯

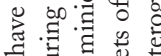
政 氜语

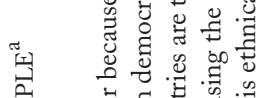

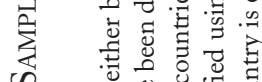
田

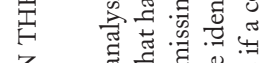
๙ 更 武国

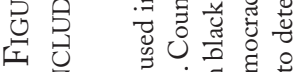
Z

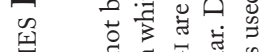

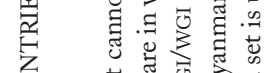
势 oै

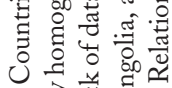

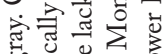

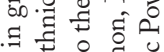
.

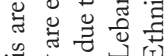

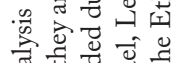
政政

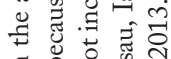
回

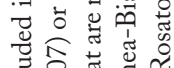

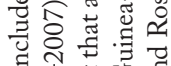
. ช8 言要害 है ن 
included in the sample are listed in Table A1 of the supplementary material. $^{39}$

The empirical analysis is divided into two sections. In the first section, the unit of analysis is group-year. The data set used in the main model covers more than 5,200 observations on 241 ethnic groups and seventy-one democracies between 1960 and 2007. In the second section, the unit of analysis is country-year, and the sample contains more than 1,600 observations.

\section{Testing Strategy and Dependent Variables}

In all tests, the sample is restricted to countries that began the year as democracies. I use two binary measures of democracy. The main models use José Antonio Cheibub, Jennifer Gandhi, and James Vreeland's indicator, which classifies regimes as democratic if the executive and legislature are selected through free and fair elections, there is more than one party, and there has been at least one alternation in power through elections. ${ }^{40}$ This data set extends the well-known measure of Przeworski and colleagues from 2002 to $2008 .{ }^{41}$ Table A14 of the supplementary material reproduces the analysis with the Carles Boix, Michael Miller, and Sebastian Rosato indicator. ${ }^{42}$

In the group-level analysis, the dependent variable is a dummy variable that takes the value 1 if a group has initiated a transition away from democracy within a given year. ${ }^{43}$ Using probit models, I test the effect of BGI on the likelihood that a group instigates a democratic reversal. In the country-level models, I employ dynamic probit models to test the effect of BGI on the probability that a democracy transitions to autocracy. ${ }^{44}$

\section{INDEPENDENT VARIABLES}

To construct measures of BGI and WGI, I use survey data from Demographic and Health Surveys, Afrobarometer, World Values Survey, Latinobarometer, International Social Survey Program, and Compara-

${ }^{39}$ Houle 2015.

${ }^{40}$ Cheibub, Gandhi, and Vreeland 2010.

${ }^{41}$ Przeworski et al. 2000.

${ }^{42}$ Boix, Miller, and Rosato 2013 add a suffrage requirement and do not require an alternation in power through elections to have taken place. Houle 2015.

${ }^{43}$ To code this variable, I used the following data sets: Archigos; EPR; Roessler 2011; and Haggard, Kaufman, and Teo 2012.

${ }^{44}$ The main country-level analysis covers thirty-nine democratic collapses. Since some breakdowns were carried out by multiple groups, the group-level analysis contains forty-three group-year observations in which a breakdown was initiated. 
tive Study of the Electoral Systems. ${ }^{45}$ Table A1 of the supplementary material lists the surveys used to calculate the values for each country. The wvs, Latinobarometer, ISSP, and CSES surveys include information on the income of the respondents. ${ }^{46}$

DHS and Afrobarometer surveys, however, do not directly ask respondents what their income is. Most countries covered by these surveys are relatively poor and monetized income is simply not relevant there. In poor countries most of the population has little access to cash income and income is not monetized. ${ }^{47}$ Afrobarometer does not ask questions about income, for example, simply because such information would be unreliable in Africa. ${ }^{48}$ Typically, researchers who use Afrobarometer or DHS to study income/poverty instead use questions about the ownership of assets. ${ }^{49}$ Some scholars argue that asset ownership is actually a better measure of economic well-being in poor countries than monetized income. ${ }^{50}$

I follow this strategy and construct an asset-based wealth (ABW) indicator of economic well-being for countries covered by DHS and Afrobarometer. DHS asks respondents whether they have the following goods: a refrigerator, a television, a radio, access to electricity, a bicycle, and a car. For each respondent, I create a variable ranging from 0 to 6 , where 0 indicates that the individual does not possess any of these goods, and 6 that the person possesses them all. Similarly, Afrobarometer asks respondents whether they own a radio, a television, and a motor vehicle. Using these questions, I construct an indicator ranging from 0 to 3 .

I use information on the ethnicity of the respondents to construct measures of BGI and WGI for each ethnic group and country. I then merge the data from the different surveys, taking advantage of the fact that many countries are covered by multiple surveys, to calculate the systematic differences between their measures. I standardize the observations to make them comparable across sources. ${ }^{51}$

\footnotetext{
${ }^{45}$ For each country-year, I use the survey that is closest in time. This method is imperfect but is valid since there is little change in inequality within countries over time. In fact, Cederman, Weidmann, and Gleditsch 2011 use a single observation on BGI in 1990 as their indicator of BGI during the post-Cold War period.

${ }^{46}$ The wvs asks respondents to place themselves on a scale from 1 to 10 (where 1 denotes the lowest income), and the ISSP and CSES directly ask their income. See Section 1 of the supplementary material for more detail and the exact questions used. Houle 2015.

${ }^{47}$ Baldwin and Huber 2010.

${ }^{48}$ Bratton 2008.

${ }^{49}$ For example, see Dionne, Inman, and Montinola 2014; Østby 2008.

${ }^{50}$ See, for example, Bratton 2008; Dionne, Inman, and Montinola 2014.

${ }^{51}$ Section 1 of the supplementary material provides more information on the different data sources as well as the method used to standardize the observations. Section 3 of the supplementary material shows that the results are robust to the use of alternative methods to standardize observations, and to the use of observations from a single survey. For example, Tables A6 and A13 use only DHS and Afrobarometer, respectively. Houle 2015.
} 


\section{GROUP-LEVEL INDICATORS}

For each ethnic group, I calculate two versions of BGI/WGI $-B G I_{1} / W G I_{1}$ and $B G I_{2} / W G I_{2}$. I first calculate $B G I_{1}$ using the same formula as Cederman, Weidmann, and Kristian Gleditsch: ${ }^{2}$

$$
B G I_{1}=\left[\log \left(\frac{g}{G}\right)\right]^{2},
$$

where $g$ refers to the average ABW score or income of members of a given ethnic group, and $G$ refers to the average ABW score or income of the country. I calculate $W G I_{1}$ simply by computing the Gini coefficient in the ABW score or in income among all members of that group. An ethnic group is only included in my data set if it is deemed politically relevant in the EPR data set..$^{53}$

I also compute a second set of indicators, $B G I_{2} / W G I_{2}$. There are two main differences between the two sets of indicators. First, while $B G I_{1} /$ $W G I_{1}$ cover all ethnic groups, $B G I_{2} / W G I_{2}$ cover only politically excluded groups, that is, those that have no representation in the government. I classify a group as excluded if it is deemed regionally autonomous, powerless, or discriminated against in the EPR data set. Second, whereas $B G I_{1}$ measures inequality between a given group and its country's average ( $G$ in equation 1), $B G I_{2}$ measures inequality between a given excluded group and politically dominant group(s). Politically dominant groups are defined as groups that have some representation in the government. These are classified in the EPR data set as junior partner, senior partner, dominant, or monopoly. Therefore, $B G I_{2}$ is calculated as follows:

$$
B G I_{2}=\left[\log \left(\frac{g}{D}\right)\right]^{2},
$$

where $g$ refers to the average ABW score or income of members of a given ethnic group, and $D$ refers to the average ABW score or income of members of politically dominant group(s). I calculate $D$ by computing the weighted average of the ABW scores or incomes of the groups in the EPR data set that are at least junior partners. The weights are determined by the size of the groups. $W I_{2}$ gives the Gini coefficient within a given excluded ethnic group.

\footnotetext{
${ }^{52}$ Cederman, Weidmann, and Gleditsch 2011.

${ }^{53}$ EPR defines an ethnic group as politically relevant "if either at least one significant political actor claims to represent the interests of that group in the national political arena or if group members are systematically and intentionally discriminated against in the domain of public politics." Ethnic Power Relations Core Dataset 2014 Codebook at http://www.icr.ethz.ch/data/epr/EPR=2014_Codebook.pdf, accessed April 9, 2015.
} 


\section{COUNTRY-LEVEL INDICATORS}

I calculate two sets of country-level indicators that mirror the grouplevel indicators. First, country-level $B G I_{1}$ is a weighted average of all group-level $B G I_{1}$ of the groups of that country. Again, the weights are determined by the size of the groups ${ }^{54}$ Country-level $B G I_{1}$ thus gives the average level of inequality between members of different ethnic groups of a country. Similarly, $W G I_{1}$ gives the weighted average of the Gini coefficients for all groups of a country. It indicates the average level of within-group inequality in that country.

To calculate country-level $B G I_{2}$, I compute the weighted average of $B G I_{2}$ for all excluded groups of that country. Therefore, the countrylevel $B G I_{2}$ of a country gives the average inequality level between politically excluded ethnic groups and the dominant group(s), defined as all politically included groups of that country. The country-level $W I_{2}$ gives the average inequality level within all excluded groups of a country.

\section{Control Variables}

\section{GROUP-LEVEL CONTROLS USED IN THE GROUP-LEVEL ANALYSIS}

The group-level analysis uses a number of group-level control variables. I include a dummy variable indicating whether an ethnic group is excluded from power. One could argue that excluded groups have more incentives to seize power. However, Philip Roessler shows that groups that are outsiders are less likely to stage coups but more likely to initiate rebellions. ${ }^{55}$ Since the vast majority of transitions to democracy occur via military or executive coups rather than civil war, it is also possible that excluded groups are less likely to cause breakdowns simply because they can less easily grab power than groups that are included in the governing coalition. The variable excluded takes the value 1 if a group has no representation in the executive. ${ }^{56} \mathrm{I}$ also control for the size of a group. Roessler finds that larger groups are more likely to stage coups and rebellions. ${ }^{57}$ Last, I include the dummy poor, which indicates whether a typical member of the group is poorer than the average citizen of the country, to account for the fact that my argument could be more relevant to rich groups that wish to limit redistribution.

\footnotetext{
${ }^{54}$ For example, consider a fictitious country with three ethnic groups $\mathrm{A}, \mathrm{B}$, and $\mathrm{C}$ that constitute respectively 40, 35, and 25 percent of the population of the country. Further assume that the grouplevel $B G I_{1}$ of these groups are 1,2 , and 0.5 , respectively. Then the country-level $B G I_{1}$ of that country would be $\left(.4^{*} 1+.35^{*} 2+.25^{*} .5\right) /(.4+.35+.25)=1.225$.

${ }^{55}$ Roessler 2011.

${ }^{56}$ These are the groups in EPR that have a status of regional autonomy, powerless, or discriminated.

${ }^{57}$ Roessler 2011.
} 


\section{COUNTRY-LEVEL CONTROLS USED IN THE GROUP- AND \\ COUNTRY-LEVEL ANALYSES}

I also use country-level controls that are usually employed in studies on democratic consolidation: gross domestic product (GDP) per capita, growth in GDP per capita, ethnic fractionalization, the proportion of the population that is Muslim, a continuous measure of oil income, a dummy variable for Western democracies, the age of the democracy, and the percent of world democracies. ${ }^{58}$

One potential problem with the data is that WGI and BGI may correlate with the geographical dispersion of ethnic groups. When groups are clustered within specific regions, they may have very different income levels than other groups that live in other regions. At the same time, WGI is likely to be moderate. If geographically concentrated groups can more easily overthrow regimes, then the estimated effect of BGI and WGI may be spurious. I use Selway's ethnic-geographical crosscuttingness (EGC) indicator to measure the extent to which ethnic groups are geographically dispersed. ${ }^{59}$ EGC takes the value 1 if there is complete dispersion of ethnic groups (that is, geography and ethnicity completely crosscut each other) and 0 if there is perfect concentration (that is, geography and ethnicity completely reinforce each other). ${ }^{60} \mathrm{I}$ also do the analysis using an alternative measure of geographical dispersion, which is available in Table A5 of the supplementary material. ${ }^{61}$

\section{COUNTRY-LEVEL CONTROLS USED IN THE COUNTRY-LEVEL ANALYSIS}

I add a variable power sharing that takes the value 1 if the executive power is shared among different groups and 0 if it is totally controlled by a single group. ${ }^{62}$ Moreover, I include a variable that gives the sum of the size of all groups that are politically dominant (that is, that have a status of at least junior partner). Section 1 of the supplementary material provides summary statistics and density distributions for the different measures of BGI and WGI and the other variables that I employ. ${ }^{63}$

\footnotetext{
${ }^{58}$ GDP per capita and growth in GDP per capita are taken from Treisman forthcoming, ethnic fractionization the proportion of the population that is Muslim from Przeworski et al. 2000, and oil income from Haber and Menaldo 2011. Western countries are defined as Western European countries, the United States, Canada, Australia, and New Zealand.

${ }^{59}$ Selway 2011.

${ }^{60}$ In Section 2 of the supplementary material, I explain how I handled missing values in the EGC data set. Houle 2015.

${ }^{61}$ Houle 2015.

${ }^{62}$ The variable takes the value 1 if more than one group is at least a junior partner.

${ }^{63}$ Houle 2015.
} 


\section{COUNTRY EXAMPLeS}

In this section, I link my argument more closely to the data set on ethnic inequality presented above through brief country examples. Table A2 of the supplementary material ranks all democracies covered in the sample from highest to lowest BGI level. ${ }^{64}$ I aim to show that: (1) many of the countries that are at the top of the ranking have also been found to have high levels of ethnic inequality by other scholars; (2) many of these countries have experienced democratic breakdowns and/or democratic instability; and (3) ethnic inequality has often contributed to instability (without necessarily being its primary driving force, however.)

As expected, Nigeria, which has experienced two democratic breakdowns, is among the most ethnically unequal countries, with the Igbos and Yorubas significantly richer than the Hausas/Fulanis. Previous research shows that ethnic inequality is particularly high in Nigeria, and that it has contributed to instability. ${ }^{65}$ Arnim Langer, Abdul Raufu Mustapha, and Frances Stewart, for instance, find that inequality between the northern and the southern regions, measured through child mortality rates, is higher in Nigeria than in Ghana or Ivory Coast. ${ }^{66}$ They further report that in the northeast the maternal mortality rate is about nine times the rate in the southwest and five times the rate in the southeast. Figures from the northwestern provinces are similar to those from the northeastern provinces. Larry Diamond argues that the presence of reinforcing cleavages, particularly ethnicity and class, is among the factors that explain the demise of the First Republic of Nigeria (1963-66). ${ }^{67}$ The $W G I_{1}$ value of the Igbos, who instigated the 1966 breakdown, is in the 10th percentile of all African groups in my data.

Peru is the most ethnically unequal country covered by the analysis due to extreme inequality between indigenous and nonindigenous populations ${ }^{68}$ Previous authors have indeed found that ethnic and class cleavages coincide in Peru. ${ }^{69}$ Corinne Caumartin, George G. Molina, and Rosemary Thorp, for example, report that indigenous people are 4.38 times as likely as nonindigenous people to find themselves in extreme poverty, making Peru the most ethnically unequal of the three countries in their study (Peru, Guatemala, and Bolivia)..$^{70}$

\footnotetext{
${ }^{64}$ Houle 2015.

${ }^{65}$ For example, see Diamond 1988; Langer, Mustapha, and Stewart 2007.

${ }^{66}$ Langer, Mustapha, and Stewart 2007.

${ }^{67}$ Diamond 1988.

${ }^{68}$ Peru has a WGI value near the average of the distribution.

${ }^{69}$ For example, see Caumartin, Molina, and Thorp 2008; Figueroa and Barrón 2005; Thorp and Paredes 2010.

${ }^{70}$ Caumartin, Molina, and Thorp 2008.
} 
Peru is one of only three countries that have witnessed three democratic reversals within the sample. Although ethnic inequality is not the only, or even main, factor explaining why the country has been so unstable, it did play a role. For example, ethnic inequality contributed to the rise of the Shining Path. ${ }^{71}$ The civil war (and the economic crisis), in turn, contributed to the ascension to power of Alberto Fujimori in 1990 and the executive coup of 1992. ${ }^{72}$ Lacking a majority in Congress, Fujimori staged the coup, allegedly to have a freer hand in fighting the Shining Path and adopting economic reforms. Therefore, "horizontal inequalities [that is, BGIs] do contribute to the social disorder in Peru, but not much in a direct way." 73

Like Peru, Guatemala is characterized by extreme inequalities between indigenous and nonindigenous populations. Caumartin and her colleagues find that indigenous people there are 4.1 times more likely to live in extreme poverty than nonindigenous people, as compared to Bolivia, for example, where they are 2.68 times more likely to live in dire poverty. ${ }^{74}$ As in the case of Peru, ethnic inequality in Guatemala has had detrimental, though indirect, consequences on democracy. For example, it contributed to the conflict between the Mayan population and the democratically elected government during the early 1980s, which facilitated the 1982 coup. $^{75}$ According to Stephan Haggard, Robert Kaufman, and Terence Teo, "the deposing of the existing government came in the context of fears of the ineffectiveness of the incumbent government to manage distributive conflicts involving the large indigenous population." 76

The indigenous population played a more direct role during the 2000 coup in Ecuador - another country with high indigenous/nonindigenous inequality. The Confederation of Indigenous Nationalities of Ecuador (CONAIE), which is the main group representing the interests of the indigenous population, along with a group of junior military officers, forced President Jamil Mahaud to flee the country. According to Haggard, Kaufman, and Teo, the CONAIE was largely motivated by

\footnotetext{
${ }^{71}$ Caumartin, Molina, and Thorp 2008; Figueroa and Barrón 2005; Thorp and Paredes 2010. It must be noted that the Shining Path is not an ethnic movement and the war was not an ethnic war; many indigenous people fought on the side of the government. In fact, the Shining Path carried out massacres against indigenous communities and most of its victims were indigenous.

${ }^{72}$ Haggard, Kaufman, and Teo 2012. Fujimori's coup was not an ethnic coup, since he had the support of the majority of the poor, including indigenous people.

${ }^{73}$ Figueroa and Barrón 2005, 1.

${ }^{74}$ Caumartin, Molina, and Thorp 2008.

${ }^{75}$ Caumartin, Molina, and Thorp 2008.

${ }^{76}$ Haggard, Kaufman, and Teo 2012, 81.
} 
distributive demands. ${ }^{77}$ Indigenous Ecuadorians have a $W G I_{1}$ level at the 36th percentile.

Unsurprisingly, South Africa ranks near the top of Table A2. The extent of ethnic inequality in South Africa and its implications for political stability are well documented. ${ }^{78}$ For example, the 2011 census showed that the average income of white households was six times greater than that of black households. ${ }^{79}$ However, South Africa has yet to experience a transition away from democracy, and political instability has diminished since the end of apartheid.

Tensions between ethnic groups played a key role during democratic breakdowns that occurred in other ethnically unequal countries, for example, in Sierra Leone in 1967 and the Central African Republic in 2003. In Sierra Leone, after the Sierra Leone People's Party-dominated by the Mendes, one of the largest ethnic groups in that country-lost an election to the Northern- (Temne- and Limba-) backed All People's Congress, a Mende-led coup deposed the new regime a few hours after power was transferred to it. In such instances, coinciding ethnic and class cleavages may contribute to the breakdown, notably by increasing the salience of ethnicity.

Canada is the most ethnically unequal Western country in the data set (twenty-first overall). This status is a result of the wide inequalities between aboriginal and nonaboriginal Canadians and between Englishand French-speaking Canadians, the latter representing 23 percent of the population. ${ }^{80}$ The fact that francophones have traditionally been poorer than anglophones has been widely cited as one of the causes of the emergence in the 1960s of the Quebec nationalist movement; reducing intergroup inequality was one of the movement's explicit goals at its inception. ${ }^{81}$

According to the 1965 Royal Commission on Bilingualism and Biculturalism, appointed by the federal government of Canada, intergroup inequality was the single most important cause of tension between English- and French-speakers. In fact, the national census of 1961 showed that in Quebec, the income of anglophones was on average 49 percent higher than that of francophones. Inequality in asset ownership

${ }^{77}$ Haggard, Kaufman, and Teo 2012, 78.

${ }^{78}$ For example, see Nattrass and Seekings 2001; Stewart 2002.

${ }^{79} \mathrm{See} \mathrm{http://www.bbc.com/news/world-africa-20138322.} \mathrm{The} \mathrm{whites} \mathrm{have} \mathrm{one} \mathrm{of} \mathrm{the} \mathrm{lowest}$ WGI $_{1}$ level of all groups. The $W_{G I}$ of blacks, however, is larger than the sample's average, which is consistent with recent reports, notably from the Organization for Economic Cooperation and Development.

${ }^{80}$ See Gee, Kobayashi, and Prus 2007.

${ }^{81}$ For example, see Fenwick 1981. 
was found to be even more pronounced, with industrial manufacturing in particular almost exclusively owned by anglophones. ${ }^{82}$ Multiple studies have further demonstrated that within-group inequality among French-speakers was low. ${ }^{83}$ French-speakers are in the 13th percentile of the $W G I_{1}$ distribution.

Although Canada has never experienced a democratic breakdown, tensions between French- and English-speakers did fuel democratic instability. For example, during the October Crisis of 1970, the kidnapping of two high-level government officials by the Quebec Liberation Front (FLQ) - one of whom (Quebec's Vice Premier and Minister of Labour Pierre Laporte) was eventually assassinated-prompted the Canadian government to deploy troops throughout Quebec and in Ottawa, and to use the War Measures Act, which suspended all civil liberties.

\section{VALIDATING THE INDICATORS}

This article uses new indicators of BGI and WGI. Before presenting the empirical analysis, it is important to show that these indicators capture the concepts of interest. As discussed above, countries that rank as the most ethnically unequal in my data set were also found to have high BGI levels by other scholars. This section further assesses the validity of the new indicators. One way to accomplish this is to examine whether groups that we already know are poorer (or richer) than other groups in their country are indeed found to be poorer (or richer) when my measure is used. In that regard, my measure does very well.

For example, in the United States, whites are found to be richer than African Americans and Latinos. In Belgium, the Flemish are wealthier than the French. As discussed above, in Canada, English-speakers are richer than French-speakers, who in turn are richer than aboriginal people. In fact, indigenous populations are found to be significantly poorer than nonindigenous populations throughout the sample, for example, in Argentina, Australia, Colombia, Ecuador, Guatemala, New Zealand, and Peru. In Brazil, blacks are poorer than mulattos, who are poorer than whites. In other Latin American countries, groups of African origin are also found to be poorer than other groups, for example, in Colombia, Ecuador, and Uruguay.

In Eastern Europe, Romas are significantly poorer than members of

${ }^{82}$ Fenwick 1981.

${ }^{83}$ Béland and de Sève 1986; Langlois 2002. 
other ethnic groups, so countries with large Roma populations appear near the top of Table A2, for example, Romania, Bulgaria, Slovakia, and Hungary. People of Turkish descent in Bulgaria are poorer than ethnic Bulgarians. In South Africa, the white populations (Afrikaners and English-speakers) are richer than the colored populations, who are richer than the black groups (Zulus and Xhosas). In Uganda, groups from the center and the south are much richer than those from the north, which explains why Uganda is the second most ethnically unequal country (see Table A2). ${ }^{84}$ This is consistent with data reported by Stewart that suggests that the average income is about twice as high in the center and south of Uganda as in the north. ${ }^{85}$ In Nigeria, Igbos and Yorubas are richer than Hausas/Fulanis.

It is much more difficult to validate the measures of WGI than BGI. Since we have less extensive prior knowledge of the level of WGI than of BGI for different groups, I cannot verify whether my measures of WGI match the expectations. However, Patrick Kuhn and Weidmann have constructed an alternative measure of WGI by combining data on light emission and geocoded ethnic settlement areas. ${ }^{86}$ To validate their measure, they also calculate WGI for seventeen African countries covered by DHS using a procedure similar to mine that is also based on asset ownership. They report that the correlation coefficient between their measure and the DHS measure is $0.42(p$-value $=0.00) .{ }^{87}$ Last, the fact that my results hold across different surveys shows that they are not driven by problems specific to any survey. ${ }^{88}$

\section{EMPIRICAL ANALYSIS}

\section{Group-Level AnAlysis}

Table 1 reports the effect of BGI on the likelihood that an ethnic group initiates a democratic breakdown along with robust standard errors clustered by country. All explanatory variables are lagged. Models 1 and 2 include groups that are politically included and those that are excluded. Between-group inequality is calculated as inequality between a group and its country's average.

Model 1 tests my hypothesis by including $B G I_{1}$ and $W G I_{1}$ along with

${ }^{84}$ Houle 2015.

${ }^{85}$ Stewart 2002.

${ }^{86}$ Kuhn and Weidmann 2014.

${ }^{87}$ This corresponds to the variable $W_{1}$ in my group-level analysis because Kuhn and Weidmann 2014 do not omit groups that are politically included.

${ }^{88}$ See Section 3 of the supplementary material. Houle 2015. 
TABLE 1

Group-Level Probit Analysis of the Effect of BGI on

Democratic BREAKDOWNS ${ }^{\mathrm{a}}$

\begin{tabular}{|c|c|c|c|c|}
\hline & 1 & 2 & 3 & 4 \\
\hline $\mathrm{BGI}_{1}$ & $\begin{array}{l}.261^{* * * *} \\
(.063)\end{array}$ & $\begin{array}{l}.329^{* * * *} \\
(.085)\end{array}$ & & \\
\hline $\mathrm{WGI}_{1}$ & $\begin{array}{l}1.515^{* *} \\
(.661)\end{array}$ & $\begin{array}{l}1.686^{* * *} \\
(.733)\end{array}$ & & \\
\hline $\mathrm{BGI}_{1}^{*} \mathrm{WGI}_{1}$ & $\begin{array}{l}-.646^{* * * *} \\
(.218)\end{array}$ & $\begin{array}{l}-.909^{\text {***** }} \\
(.278)\end{array}$ & & \\
\hline $\mathrm{BGI}_{2}$ & & & $\begin{array}{l}.484^{* * * *} \\
(.107)\end{array}$ & $\begin{array}{l}.491^{\text {**** }} \\
(.097)\end{array}$ \\
\hline $\mathrm{WGI}_{2}$ & & & $\begin{array}{c}.783 \\
(1.089)\end{array}$ & $\begin{array}{c}.93 \\
(1.244)\end{array}$ \\
\hline $\mathrm{BGI}_{2}^{*} \mathrm{WGI}_{2}$ & & & $\begin{array}{c}-1.016^{* * * *} \\
(.252)\end{array}$ & $\begin{array}{c}-1.017^{\text {**** }} \\
(.218)\end{array}$ \\
\hline Size & $\begin{array}{l}1.098^{* * * *} \\
(.315)\end{array}$ & $\begin{array}{l}1.118^{* * * *} \\
(.354)\end{array}$ & $\begin{array}{c}2.972 \\
(2.048)\end{array}$ & $\begin{array}{c}3.519^{*} \\
(1.944)\end{array}$ \\
\hline Excluded & $\begin{array}{l}-.576^{* * * *} \\
(.219)\end{array}$ & $\begin{array}{l}-.499^{* *} \\
(.235)\end{array}$ & & \\
\hline Poor & $\begin{array}{l}-.376^{* *} \\
(.168)\end{array}$ & $\begin{array}{c}-.312^{*} \\
(.179)\end{array}$ & & \\
\hline GDP per capita & $\begin{array}{l}-.211^{*} \\
(.126)\end{array}$ & $\begin{array}{l}-.136 \\
(.142)\end{array}$ & $\begin{array}{l}-.709^{*} \\
(.42)\end{array}$ & $\begin{array}{c}-.783 \\
(.576)\end{array}$ \\
\hline Growth & $\begin{array}{l}.027 \\
(.017)\end{array}$ & $\begin{array}{l}.027 \\
(.018)\end{array}$ & $\begin{array}{l}.142^{* * * *} \\
(.037)\end{array}$ & $\begin{array}{l}.144^{* * * *} \\
(.04)\end{array}$ \\
\hline Oil & $\begin{array}{l}-.148 \\
(.268)\end{array}$ & $\begin{array}{l}-.163 \\
(.293)\end{array}$ & $\begin{array}{c}2.101^{* *} \\
(.822)\end{array}$ & $\begin{array}{c}2.391^{*} \\
(1.407)\end{array}$ \\
\hline Ethnic frac. & $\begin{array}{l}.004 \\
(.005)\end{array}$ & $\begin{array}{l}.004 \\
(.005)\end{array}$ & $\begin{array}{l}.047^{* * * *} \\
(.018)\end{array}$ & $\begin{array}{l}.032^{* *} \\
(.016)\end{array}$ \\
\hline Muslim & $\begin{array}{l}-.001 \\
(.002)\end{array}$ & $\begin{array}{l}-.001 \\
(.002)\end{array}$ & $\begin{array}{l}.013 \\
(.009)\end{array}$ & $\begin{array}{l}.013 \\
(.01)\end{array}$ \\
\hline Western & $\begin{array}{c}-.57^{* * * *} \\
(.209)\end{array}$ & $\begin{array}{l}-.704^{* * * *} \\
(.214)\end{array}$ & & \\
\hline Percent world dem. & $\begin{array}{c}-3.969^{* * * *} \\
(.753)\end{array}$ & $\begin{array}{c}-4.514^{* * * *} \\
(.836)\end{array}$ & $\begin{array}{l}5.66^{*} \\
(3.314)\end{array}$ & $\begin{array}{c}5.374^{*} \\
(3.269)\end{array}$ \\
\hline Age & $\begin{array}{c}-.061^{* * * *} \\
(.019)\end{array}$ & $\begin{array}{l}-.063^{* * * *} \\
(.02)\end{array}$ & $\begin{array}{c}-.708^{* * * *} \\
(.253)\end{array}$ & $\begin{array}{c}-.649^{* * * *} \\
(.234)\end{array}$ \\
\hline Geo. disp. & & $\begin{array}{l}.084 \\
(.446)\end{array}$ & & $\begin{array}{c}-2.414 \\
(1.577)\end{array}$ \\
\hline Number of countries & 71 & 66 & 61 & 57 \\
\hline Number of ethnic groups & 241 & 224 & 117 & 110 \\
\hline $\mathrm{N}$ & 5,208 & 4,967 & 2,110 & 2,012 \\
\hline Log-pseudolik. & -168.152 & -152.323 & -12.028 & -11.701 \\
\hline
\end{tabular}

Robust standard errors clustered by country in parentheses; all explanatory variables are lagged; ${ }^{* * * *} \mathrm{p}<.01$, ** $\mathrm{p}<.05$ and ${ }^{*} \mathrm{p}<.1$

${ }^{a}$ For all ethnic groups, the group-level $B G I_{1}$ gives inequality between that group and its country's average. The group-level $W_{G I_{1}}$ refers to inequality within each ethnic group and covers all ethnic groups. The group-level $B_{B_{2}}$ includes only politically excluded groups, and measures inequality between that group and its country's dominant group(s) (defined as all politically included groups). The group-level $W I_{2}$ refers to inequality within each ethnic group and covers only excluded groups. 
their interaction. The hypothesis is supported if the coefficient on $B G I_{1}$ is positive while the one on $B G I_{1}{ }^{*} W G I_{1}$ is negative. To see this, notice that if the coefficient on $B G I_{1}$ is positive, $B G I_{1}$ increases the likelihood of democratic reversals when $W G I_{1}$ is zero. If the coefficient on $B G I_{1}{ }^{*} W G I_{1}$ is negative, however, the effect of $B G I_{1}$ weakens and may even reverse as $B G I_{1}$ increases.

As shown in model 1, both variables have the expected signs and are statistically significant at the 1 percent level. Between-ethnic group inequality increases the chances that a group initiates a transition to autocracy when $W G I_{1}$ is low, but its effect diminishes as $W G I_{1}$ increases. In addition to testing the significance of each individual coefficient, I perform a joint test of $B G I_{1}$ and $B G I_{1}{ }^{*}{ }_{W G I_{1}}{ }^{89}$ The chi-squared statistic is 33.05 and is statistically significant at the 1 percent level $(p$-value $=0.0000)$. Table A9 in the supplementary material further shows that BGI has little effect on breakdowns when one does not condition for WGI $(p$-value $=0.79) \cdot{ }^{90} \mathrm{As}$ demonstrated by Chunrong $\mathrm{Ai}$ and Edward Norton, caution is required when interpreting coefficients on interaction terms with nonlinear models. ${ }^{91}$ Therefore, in Figure $3 \mathrm{I}$ show the marginal effect of $B G I_{1}$ on the probability that a group initiates a breakdown at different levels of $W I_{1}$, and 95 percent confidence intervals. As expected, $B G I_{1}$ harms democracies at low levels of $W G I_{1}$. But when $W G I_{1}$ reaches a Gini coefficient of about 0.37 , the effect of $B G I_{1}$ is no longer statistically significant at the 5 percent level.

Figure 3 also shows that once $W I_{1}$ attains a value of about 0.65 , the effect of $B G I_{1}$ reverses and becomes negative. This finding is consistent with the theory on crosscutting cleavages that asserts that deepening one cleavage may reduce the destabilizing effect of other cleavages. When interclass inequality is high, cross-ethnic coalitions based on alternative cleavages, such as social class, are less likely to challenge democracy. ${ }^{92}$ Under such conditions, increasing BGI may weaken the harmful effect of interclass inequality by dividing social classes. Only about 1 percent of the observations have $W G I_{1}$ values above 0.65 , so this finding has to be interpreted with caution.

Figure 4 presents the effect of $B G I_{1}$ on the predicted probability of a transition away from democracy at low (10th percentile) and high (90th percentile) levels of $W G I_{1}$. As expected, when $W_{1} I_{1}$ is low, groups with high $B G I_{1}$ levels are likely to initiate a transition away from democ-

\footnotetext{
${ }^{89} \mathrm{I}$ use Wald tests, which are asymptotically equivalent to $\log$-likelihood ratio tests but preferable when standard errors are clustered.

${ }^{90}$ Houle 2015.

${ }^{91} \mathrm{Ai}$ and Norton 2003.

${ }^{92}$ See Boix 2003; Acemoğlu and Robinson 2006.
} 


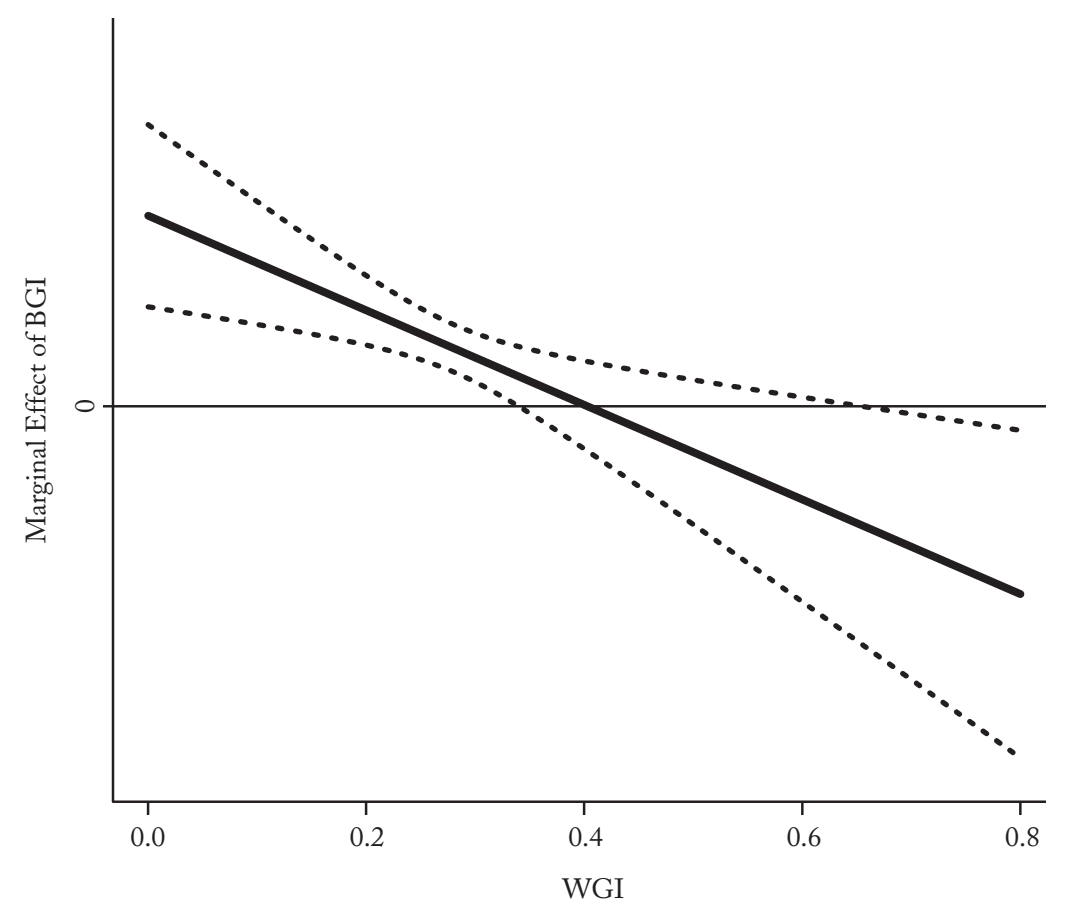

FiguRE 3

Marginal Effect of BGi on Democratic Breakdowns across WGI Levels: Group-Level Analysis ${ }^{\mathrm{a}}$

\footnotetext{
${ }^{\mathrm{a}}$ Based on estimates from model 1 of Table 1 . Dashed lines are 95 percent confidence intervals. For all ethnic groups, BGI gives inequality between that group and its country's average. WGI refers to inequality within each ethnic group and covers all ethnic groups.
}

racy. Among low $W G I_{1}$ groups, increasing $B G I_{1}$ from its mean (1.296) by one standard deviation (5.145) increases the predicted probability of a breakdown fifteen times (from 0.044 to 0.66 percent) per year. The same change would actually reduce the likelihood of a breakdown from 0.106 to 0.027 percent among high $W_{1} I_{1}$ groups.

In Table 1, model 2 shows that the results are robust to the inclusion of the indicator of geographical dispersion of groups. Figure A9 in the supplementary material gives the marginal effect of BGI on democratic breakdowns with calculations based on this model. ${ }^{93}$ The marginal effect figures for all other estimations included in this article are re-

${ }^{93}$ Houle 2015. 


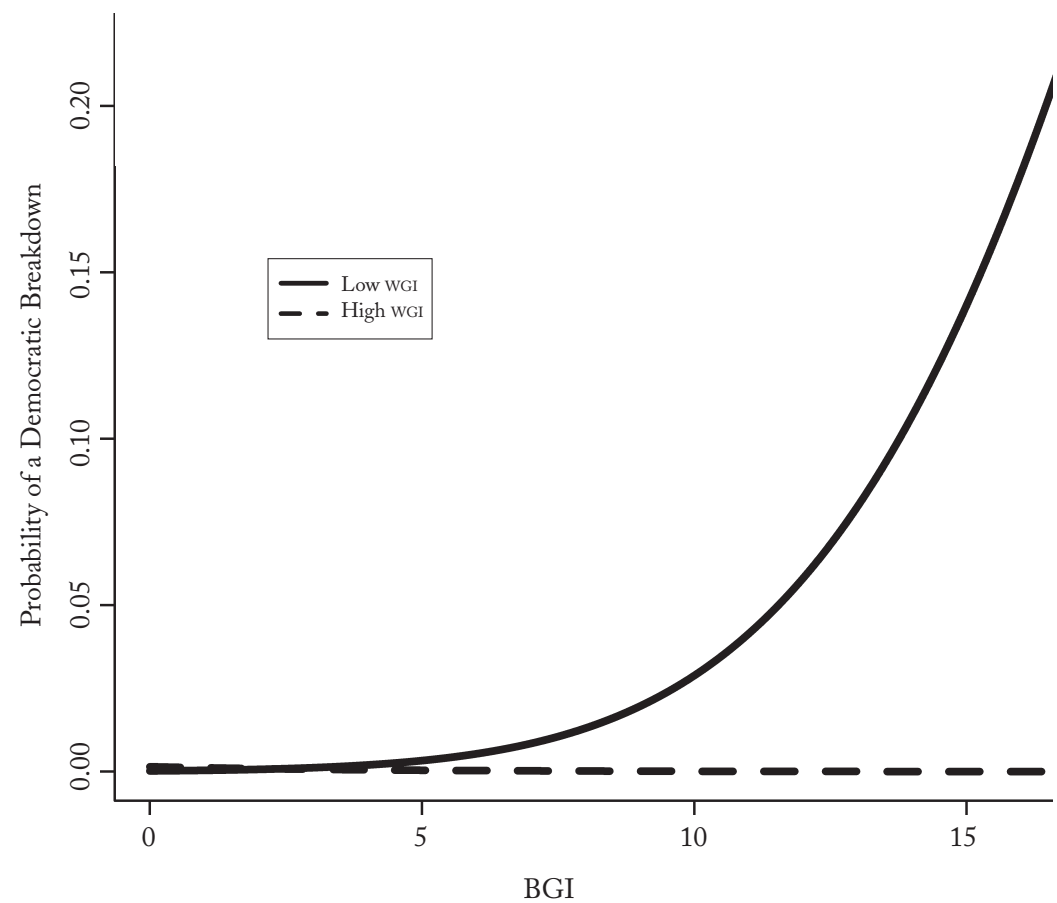

FIGURE 4

Effect of BGI on Democratic Breakdown: Group-Level Analysis ${ }^{a}$

\footnotetext{
${ }^{a}$ Based on estimates from model 1 of Table 1 . For all ethnic groups, BGI gives inequality between that group and its country's average. WGI refers to inequality within each ethnic group and covers all ethnic groups.
}

ported in Section 8 of the supplementary material. ${ }^{94}$ Models 3 and 4 reproduce models 1 and 2, but include only politically excluded groups $\left(B G I_{2} / W G I_{2}\right) .{ }^{95}$ In models 3 and 4, BGI yields the level of inequality between an excluded group and the politically dominant group(s) of its country. ${ }^{96}$ Results are unchanged. In models 2 through 4, $B G I_{1}$ and $B G I_{1}{ }^{*}$ $W G I_{1}$, and $B G I_{2}$ and $B G I_{2}{ }^{*} W G I_{2}$, are again found to be jointly significant at the one percent level ( $p$-value $=0.0000$ in all specifications).

${ }^{94}$ Houle 2015.

${ }^{95}$ Western and poor drop automatically from the regressions using $B G I_{2}$ and $W G I_{2}$. This is because no excluded group has been at the origin of a breakdown in a Western democracy during the period covered. Similarly, not a single poor group that was excluded has instigated a transition.

${ }^{96}$ The number of observations decreases significantly because all groups that have some representation in the government are dropped. 


\section{Country-Level Analysis}

In this section I look at the question of whether countries with higher levels of BGI are more likely to experience democratic breakdowns. Such an analysis enables us to examine whether democracies with reinforcing cleavage structures are the most unstable, which is the question addressed by much of the early literature on democratic stability ${ }^{97}$ As illustrated by Figure 1, case 3, the incentives of a group to overthrow a democracy, in fact, may depend not only on its own WGI, but also on that of other groups.

Table 2 uses dynamic probit models to test the effect of BGI on the likelihood that a democracy transitions to autocracy. The estimates give the effect of each independent variable on the probability that a democracy breaks down within a given year. Positive coefficients indicate that the corresponding independent variable increases the likelihood of democratic reversal.

Models 1 and 2 measure inequality between all ethnic groups and the country's average. I test my hypothesis by using $B G I_{1}, W G I_{1}$, and their interaction. In both models, $B G I_{1}$ increases the chances that a democracy collapses when $W G I_{1}$ is low, but its effect diminishes and eventually reverses as WGI increases. Moreover, $B G I_{1}$ and $B G I_{1}{ }^{*} W G I_{1}$ are jointly significant at the one percent level ( $p$-value $=0.0000$ in both models). Table A10 of the supplementary material demonstrates that BGI does not affect the likelihood of transition away from democracy when one does not condition for WGI $(p$-value $=0.631) .{ }^{98}$

Figure 5 shows the marginal effect of $B G I_{1}$ on the probability that a democracy collapses at different values of $W G I_{1}$. When $W G I_{1}$ is below $0.35, B G I_{1}$ increases the likelihood of democratic breakdown and the relationship is significant at the 5 percent level. Figure 6 gives the effect of $B G I_{1}$ on the predicted probability of a transition away from democracy at low and high WGI $_{1}$ levels.

In Table 2, models 3 and 4 replicate models 1 and 2, but include only the politically excluded groups in the calculation of $B G I_{2}$ and $W G I_{2}$. Moreover, the reference group is the dominant group(s), defined as all politically included groups rather than the country's average ABW score or income. Therefore, $\mathrm{BGI}_{2}$ reports the average level of inequality between politically excluded and dominant groups, and $W_{G I}$ reports the average level of inequality within the former. Results are unchanged. In both models, $\mathrm{BGI}_{2}$ and $\mathrm{BGI}_{2}{ }^{*} \mathrm{WGI}_{2}$ are jointly significant ( $p$-values 0.0117 and 0.0224 , respectively).

${ }^{97}$ For example, Lipset 1960.

${ }^{98}$ Houle 2015. 
TABLE 2

Country-Level Dynamic Probit Analysis of the Effect of BGI on DEMOCRATIC BREAKDOWNS ${ }^{\mathrm{a}}$

\begin{tabular}{|c|c|c|c|c|}
\hline & 1 & 2 & 3 & 4 \\
\hline $\mathrm{BGI}_{1}$ & $\begin{array}{l}1.336^{* * * *} \\
(.284)\end{array}$ & $\begin{array}{l}1.471^{* * * *} \\
(.301)\end{array}$ & & \\
\hline $\mathrm{WGI}_{1}$ & $\begin{array}{l}4.492^{* * * *} \\
(1.103)\end{array}$ & $\begin{array}{l}5.233^{* * * *} \\
(1.207)\end{array}$ & & \\
\hline $\mathrm{BGI}_{1}^{*} \mathrm{WGI}_{1}$ & $\begin{array}{c}-3.652^{* * * *} \\
(.798)\end{array}$ & $\begin{array}{l}-4 \\
\quad(.836)\end{array}$ & & \\
\hline $\mathrm{BGI}_{2}$ & & & $\begin{array}{l}.194^{* *} \\
(.08)\end{array}$ & $\begin{array}{l}.217^{\text {** }} \\
(.09)\end{array}$ \\
\hline $\mathrm{WGI}_{2}$ & & & $\begin{array}{l}2.325^{* * * *} \\
(.74)\end{array}$ & $\begin{array}{l}2.558^{* * *} \\
(.849)\end{array}$ \\
\hline $\mathrm{BGI}_{2} * \mathrm{WGI}_{2}$ & & & $\begin{array}{l}-.648^{* * * *} \\
(.238)\end{array}$ & $\begin{array}{l}-.71^{* * * *} \\
(.271)\end{array}$ \\
\hline GDP pc & $\begin{array}{l}-.1 \\
(.175)\end{array}$ & $\begin{array}{l}.003 \\
(.184)\end{array}$ & $\begin{array}{c}-.287^{* *} \\
(.146)\end{array}$ & $\begin{array}{l}-.25 \\
(.156)\end{array}$ \\
\hline Growth & $\begin{array}{l}.02 \\
(.02)\end{array}$ & $\begin{array}{l}.016 \\
(.021)\end{array}$ & $\begin{array}{l}.021 \\
(.023)\end{array}$ & $\begin{array}{l}.018 \\
(.023)\end{array}$ \\
\hline Oil & $\begin{array}{c}-.397 \\
(.289)\end{array}$ & $\begin{array}{l}-.313 \\
(.269)\end{array}$ & $\begin{array}{c}-.272 \\
(.238)\end{array}$ & $\begin{array}{l}-.156 \\
(.234)\end{array}$ \\
\hline Ethnic frac. & $\begin{array}{c}-.007 \\
(.006)\end{array}$ & $\begin{array}{l}-.01^{*} \\
(.006)\end{array}$ & $\begin{array}{c}-.008 \\
(.008)\end{array}$ & $\begin{array}{c}-.011 \\
(.008)\end{array}$ \\
\hline Muslim & $\begin{array}{l}.002 \\
(.003)\end{array}$ & $\begin{array}{l}.003 \\
(.003)\end{array}$ & $\begin{array}{c}-.001 \\
(.003)\end{array}$ & $\begin{array}{c}-.001 \\
(.003)\end{array}$ \\
\hline Western & $\begin{array}{l}-.77 \\
(.49)\end{array}$ & $\begin{array}{l}-.814 \\
(.565)\end{array}$ & $\begin{array}{l}-.62 \\
(.492)\end{array}$ & $\begin{array}{l}-.614 \\
(.547)\end{array}$ \\
\hline Percent world dem. & $\begin{array}{c}-4.68^{\text {**** }} \\
(.798)\end{array}$ & $\begin{array}{c}-5.01^{* * * *} \\
(.882)\end{array}$ & $\begin{array}{c}-4.105^{* * * *} \\
(.9)\end{array}$ & $\begin{array}{c}-4.119^{\text {**** }} \\
(.938)\end{array}$ \\
\hline Age & $\begin{array}{c}-.008 \\
(.006)\end{array}$ & $\begin{array}{l}-.008 \\
(.006)\end{array}$ & $\begin{array}{c}-.003 \\
(.007)\end{array}$ & $\begin{array}{c}-.002 \\
(.007)\end{array}$ \\
\hline Size dom. & $\begin{array}{c}-1.761^{* * * *} \\
(.431)\end{array}$ & $\begin{array}{c}-1.957^{* * * *} \\
(.484)\end{array}$ & $\begin{array}{c}-1.349^{* * *} \\
(.63)\end{array}$ & $\begin{array}{c}-1.624^{* *} \\
(.642)\end{array}$ \\
\hline Power sharing & $\begin{array}{l}-.085 \\
(.229)\end{array}$ & $\begin{array}{l}-.233 \\
(.252)\end{array}$ & $\begin{array}{l}.055 \\
(.23)\end{array}$ & $\begin{array}{l}-.009 \\
(.254)\end{array}$ \\
\hline Geo. disp. & & $\begin{array}{l}-.813^{* *} \\
(.389)\end{array}$ & & $\begin{array}{r}-.757^{*} \\
(.447)\end{array}$ \\
\hline Number of countries & 71 & 66 & 61 & 57 \\
\hline $\mathrm{N}$ & 1,607 & 1,524 & 1,222 & 1,168 \\
\hline Log-pseudolik. & -137.71 & -127.881 & -125.542 & -120.307 \\
\hline
\end{tabular}

Robust standard errors clustered by country in parentheses; all explanatory variables are lagged; $* * * * 0.01$, *** $<<.05$ and ${ }^{*} \mathrm{p}<.1$.

${ }^{\text {a }}$ The country-level $B G I_{1}$ refers to the average inequality level between all ethnic groups of a country and the country's average - that is, it is the weighted average of all the group-level $B G I_{1}$ of a country. The country-level $W G I_{1}$ refers to the average inequality level within all ethnic groups of a country - that is, it is the weighted average of all the group-level $W G I_{1}$ of a country. The country-level $B G I_{2}$ refers to the average inequality level between politically excluded ethnic groups and the dominant ethnic groups (defined as all politically included groups) - that is, it is the weighted average of all the group-level $B G I_{2}$ of a country. The country-level $W_{2} I_{2}$ refers to the average inequality level within all politically excluded ethnic groups of a country - that is, it is the weighted average of all the group-level $W I_{2}$ of a country. 


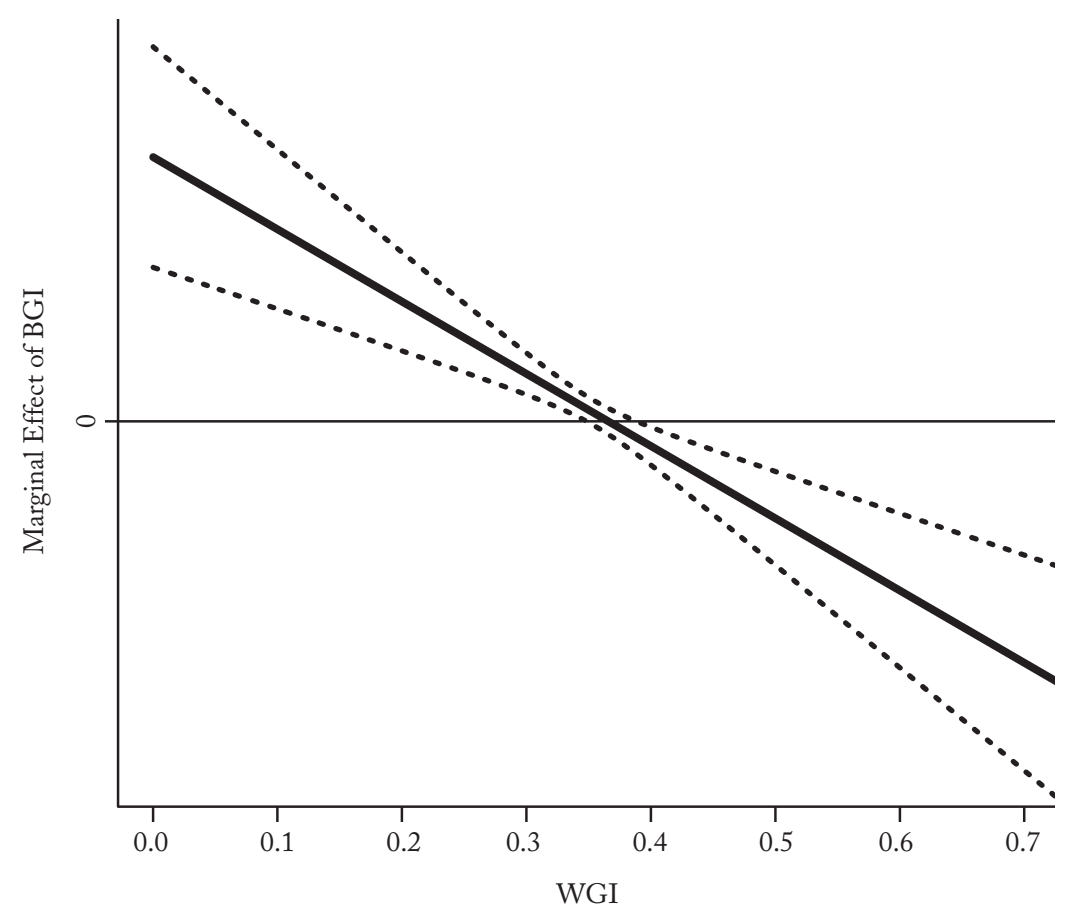

FiguRE 5

Marginal Effect of BGI on Democratic Breakdowns across WGI LeVels: Country-Level Analysis ${ }^{\mathrm{a}}$

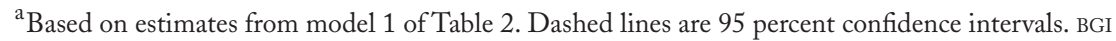
refers to the average inequality level between all ethnic groups of a country and the country's average. WGI refers to the average inequality level within all ethnic groups of a country.
}

Most democratic breakdowns are the result of coups, including executive coups. In principle, civil wars could also directly cause transitions away from democracy, although such instances are rare in practice. Therefore, in Section 5 of the supplementary material, I estimate the effect of BGI on coups and rebellions waged against democracies, including those that have been unsuccessful..$^{99} \mathrm{I}$ use the civil war data of the Peace Research Institute Oslo and the coup data of Jonathan Powell and Clayton Thyne, which include both failed and successful coups. ${ }^{100}$ Again, results suggest that BGI increases the likelihood

\footnotetext{
${ }^{99}$ Houle 2015.

${ }^{100}$ Powell and Thyne 2011.
} 


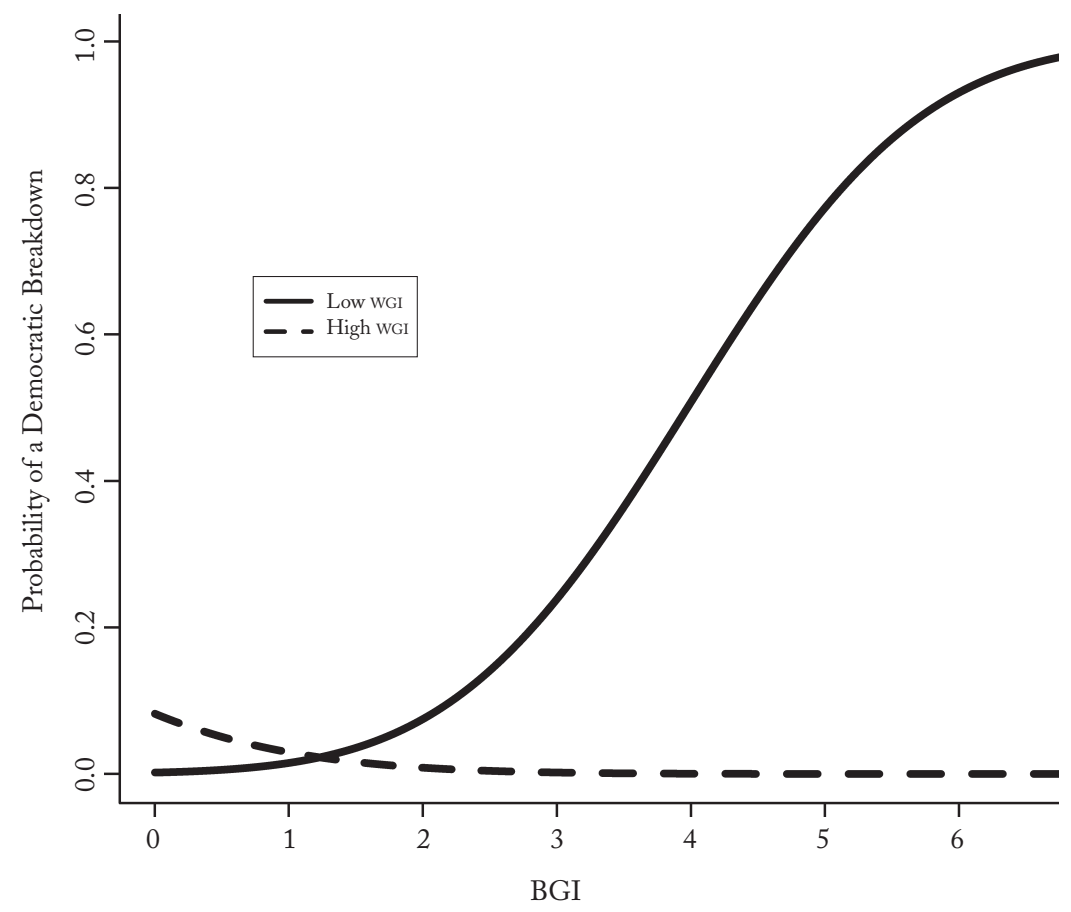

FIGURE 6

EFFect of BGI on Democratic Breakdowns: Country-Level Analysis ${ }^{a}$

${ }^{a}$ Based on estimates from model 1 of Table 2. BGI refers to the average inequality level between all ethnic groups of a country and the country's average. WGI refers to the average inequality level within all ethnic groups of a country.

that a coup or rebellion is initiated within a given year, but only when WGI is low. ${ }^{101}$

\section{Discussion of the Control Variables}

Most of the control variables affect democracies in the ways predicted by the previous literature. As shown by Przeworski and colleagues, higher levels of GDP per capita foster consolidation. ${ }^{102}$ However, the effect is relatively weak, which is consistent with the findings of Daron

${ }^{101}$ I did not perform this analysis at the group-level because of the lack of information on the ethnicity of coup leaders outside sub-Saharan Africa. However, in Section 6 of the supplementary material I do perform this analysis at the group level using only sub-Saharan African democracies. Houle 2015. I use the data set of Roessler 2011, which identifies the ethnicity of coup or rebellion leaders.

${ }^{102}$ Przeworski et al. 2000. 
Acemoğlu and associates. ${ }^{103}$ Nonetheless, when Western is omitted, income has a strong and highly significant stabilizing effect on democracy in most models (available upon request). ${ }^{104}$

Economic crises have little effect on democratic stability. This result is in accord with my earlier findings that suggest that economic crises predict transitions to democracy better than from it. ${ }^{105}$ Moreover, democracies in which the executive is shared among many groups are somewhat more stable. Large ethnic groups are more likely to create instability, which is consistent with the findings of Roessler. ${ }^{106}$

Politically excluded groups are less likely to initiate transitions to autocracy than are groups that are politically included. Since the overwhelming majority of democratic breakdowns take the form of military or executive coups rather than civil war, this finding is also consistent with Roessler, who finds that excluded groups are less likely to stage coups but more likely to initiate civil wars. ${ }^{107}$ As expected, older democracies are more resilient and democratic breakdowns are less likely to occur in years in which a large proportion of countries are democratic.

Oil wealth is not always linked to democratic instability. This is consistent with findings in my earlier work that oil harms democratization but not democratic consolidation, as illustrated by oil-rich democracies such as Norway. ${ }^{108}$ It is also in accord with the findings of Stephen Haber and Victor Menaldo that oil has little effect on regimes, and of Dunning that oil may, under certain conditions, even help consolidation. ${ }^{109}$

\section{Robustness Tests}

The supplementary material presents several additional robustness tests. ${ }^{110}$ First, in Table A14, I run the main analysis with the Boix and associates measure of democracy rather than the Cheibub and associates measure. ${ }^{111}$ Doing so enables me to cover four additional countries-Belarus, Mozambique, Russia, and South Africa-that are defined by Cheibub and colleagues as authoritarian. ${ }^{112}$ Table A15 shows that the results are robust to the inclusion of country and year

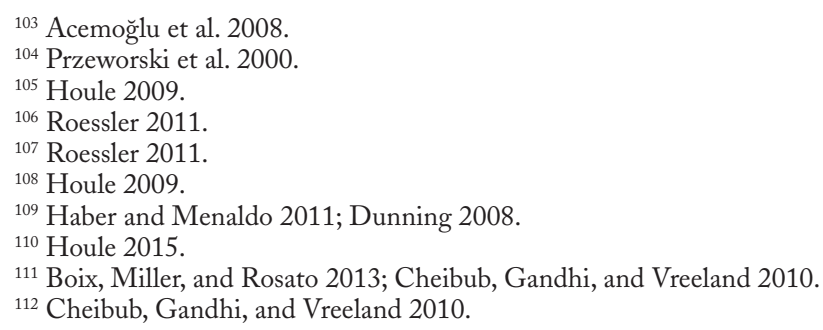


fixed effects. In Table A16, I include additional control variables: a dummy variable for former British colonies, religious fractionalization, a dummy variable for countries that did not exist prior to 1946, and the number of previous democratic breakdowns. ${ }^{113}$ Moreover, Table A17 shows that the results are not driven by outliers. Table A5 uses an alternative measure of the geographical dispersion of groups. ${ }^{114}$

One potential problem with the analysis presented thus far is that not all democratic breakdowns are driven by ethnic tensions. It is, of course, unrealistic to believe that a single explanation could account for all transitions to autocracy. In Section 6 of the supplementary material, I reproduce the analysis including only sub-Saharan African countries and using Roessler's data set, which indicates the ethnicity of coup or rebellion leader(s) for each coup and rebellion that occurred in subSaharan Africa. ${ }^{115}$ I use this data set to determine whether ethnicity played a key role during the breakdown. I also test the effect of BGI on coups and rebellions, including those that were unsuccessful. Again, results support my hypothesis.

There are two other issues that deserve to be discussed. First, if some of the regressors are highly collinear, the estimations could have multicollinearity problems. The correlation between $B G I_{1}$ and $W G I_{1}$ is 0.354 in the group-level data and 0.324 in the country-level data. To further assess whether there is multicollinearity, I rerun model 1 of Tables 1 and 2 with ordinary least squares to calculate the variance inflator factors (VIF) of the variables included in the regressions (without the interaction terms). None attains a VIF of 10 , which is usually the threshold set to detect whether there is multicollinearity. In both regressions, the variable with the highest VIF is GDP per capita (5.19 and 4.66, respectively). In the regressions, $B G I_{1}$ has VIFs of 1.23 and 1.36, and $W G I_{1}$ of 1.71 and 1.85 , respectively.

Second, one could argue that my results are affected by endogeneity. Following the argument of Allen Meltzer and Scott Richard, we should expect democracies to reduce inequality, which could explain why BGI is associated with higher probabilities of transition away from democracy, although it is less clear why BGI would only be harmful at low WGI levels. ${ }^{116}$ Unfortunately, it is difficult to instrument for BGI since it would require instruments correlated with BGI and WGI for each ethnic group. Such information is simply unavailable.

\footnotetext{
${ }^{113}$ Data on the additional controls are taken from Przeworski et al. 2000.

${ }^{114}$ Since most of the surveys used were conducted after 1980, Table A18 covers only the post-1980 period; Houle 2015.

${ }^{115}$ Roessler 2011; Houle 2015.

${ }^{116}$ Meltzer and Richard 1981.
} 
However, we can be relatively confident that the findings are not the result of reverse causality. First, inequality is notoriously persistent within countries over time. Many existing studies use a very low number of observations for each country to infer missing values. For example, Cederman and associates use a single year, 1990, for each country to construct their BGI measure for the full post-Cold War period. ${ }^{117}$ This, combined with the fact that many of my models include only democracies-meaning that being a democracy per se cannot affect the estimations-suggests that it is unlikely that my results are driven by the short-term effect of democracy on BGI.

One remaining possibility is that older democracies have had more time than younger ones to reduce inequality. If older democracies are also more resilient, for example, because their institutions are more developed, we could have a spurious negative relationship between inequality and the survival of democracy. Given that all models control for the age of the regime, the results are not driven by the effect of the age of the democracy.

\section{Conclusion}

While most scholars agree that inequality harms the consolidation of democratic regimes, few studies have looked at the political implications of inequality between different groups-for example, defined along ethnic lines - on the survival of democracies. This article unpacks the relationship between inequality and democracy, and argues that between-ethnic-group inequality harms democracies when withinethnic-group inequality is low, but that its destabilizing effect diminishes as WGI increases. Using group- and country-level data from more than seventy-one democracies, I test the effect of ethnic inequality on democratic consolidation. Although not definitive, my findings do provide support in favor of my hypothesis: when WGI is low, BGI is found to harm democracy, but when WGI is high, BGI has little effect.

One caveat is that, evidenced by some of the country examples, ethnic inequality is usually a structural cause of transition away from democracy, not an immediate one. To a certain extent this is unsurprising since ethnic inequality is largely constant through time, making it unlikely to explain the timing of a breakdown. Studies on how overall or interclass inequality, ethnic/religious diversity, and religious affiliation, for

${ }^{117}$ Cederman, Weidmann, and Gleditsch 2011. 
instance, affect democratic reversals or civil wars face the same problem. For example, Acemoğlu and James Robinson argue that interclass inequality causes transitions away from democracy, but assume that exogenous shocks serve as triggers. ${ }^{118}$ More research on how ethnic inequality and other structural factors interact with potential triggers to cause the dismantling of democracy ought to be conducted.

\section{SupPlementary Material}

Supplementary material for this article can be found at http://doi.dx.org.10.1017/ S0043887115000106.

\section{REFERENCES}

Acemoğlu, Daron, Simon Johnson, James A. Robinson, and Pierre Yared. 2008. "Income and Democracy." American Economic Review 98, no. 3: 808-42.

Acemoğlu, Daron, and James A. Robinson. 2006. Economic Origins of Dictatorship and Democracy. New York, N.Y.: Cambridge University Press.

Afrobarometer. At www.afrobarometer.org, accessed June 20, 2014.

Ai, Chunrong, and Edward C. Norton. 2003. "Interaction Terms in Logit and Probit Models." Economics Letters 80, no. 1: 123-29.

Baldwin, Kate, and John D. Huber. 2010. "Economic versus Cultural Differences: Forms of Ethnic Diversity and Public Goods Provision." American Political Science Review 104, no. 4: 644-62.

BBC. 2012. "South Africa's Census: Racial Divide Continuing." October 30. At http://www.bbc.com/news/world-africa-20138322, accessed July 20, 2014.

Béland, François, and Michel de Sève. 1986. "L'inégalité et la discrimination sexuelles et linguistiques au Québec." Canadian Review of Sociology and Anthropology 23, no. 3: 309-30.

Boix, Carles. 2003. Democracy and Redistribution. New York, N.Y.: Cambridge University Press.

Boix, Carles, Michael Miller, and Sebastian Rosato. 2013. "A Complete Data Set of Political Regimes, 1800-2007." Comparative Political Studies 46, no. 12: 1523-54.

Bratton, Michael. 2008. "Poor People and Democratic Citizenship in Africa." In Anirudh Krishna, ed., Poverty, Participation and Democracy: A Global Perspective. New York, N.Y.: Cambridge University Press.

Bratton, Michael, and Nicolas van de Walle. 1997. Democratic Experiments in Africa: Regime Transitions in Comparative Perspective. New York, N.Y.: Cambridge University Press.

Caumartin, Corinne, George Gray Molina, and Rosemary Thorp. 2008. "Inequality, Ethnicity and Political Violence in Latin America: The Cases of Bolivia, Guatemala and Peru." In Frances Stewart, ed., Horizontal Inequalities and Conflict: Understanding Group Violence in Multiethnic Societies. New York, N.Y.: Palgrave Macmillan.

Cederman, Lars-Erik, Jan Ketil Rød, and Nils B. Weidmann. 2006. "GeoReferencing of Ethnic Groups: Creating a New Dataset." Paper presented at ${ }^{118}$ Acemoğlu and Robinson 2006. 
the GROW Workshop at the Peace Research Institute Oslo, February 10-11. At http://isites.harvard.edu/fs/docs/icb.topic 244666.files/Cederman_Rod_Weidman_Geo_Ethnic_Grps_PRIO_2007.pdf, accessed July 102014.

Cederman, Lars-Erik, Nils B. Weidmann, and Kristian Skrede Gleditsch. 2011. "Horizontal Inequalities and Ethnonationalist Civil War: A Global Comparison." American Political Science Review 105, no. 3: 478-95.

Cederman, Lars-Erik, Andreas Wimmer, and Brian Min. 2010. "Why Do Ethnic Groups Rebel? New Data and Analysis.” World Politics 62, no. 1 (January): 87-119.

Chandra, Kanchan 2005. "Ethnic Parties and Democratic Stability." Perspectives on Politics 3, no. 2: 235-52.

Cheibub, José Antonio, Jennifer Gandhi, and James Raymond Vreeland. 2010. "Democracy and Dictatorship Revisited." Public Choice 143, no. 1-2: 67-101.

Cohen, Abner. 1969. Custom and Politics in Urban Africa: A Study of Hausa Migrants in Yoruba Towns. Berkeley, Calif.: University of California Press.

Collier, Paul, and Anke Hoeffler. 2005. "Coup Traps: Why Does Africa Have So Many Coups d'Etat?” Manuscript, University of Oxford. At http://users.ox.ac .uk/ econpco/research/pdfs/Coup-traps.pdf, assessed July 32014.

Comparative Study of Electoral Systems. At www.cses.org, accessed June 20, 2014.

Dahl, Robert A. 1956. A Preface to Democratic Theory. Chicago, Ill.: University of Chicago Press.

— 1971. Polyarchy: Participation and Opposition. New Haven, Conn.: Yale University Press.

Demographic and Health Surveys. At http://www.measuredhs.com, accessed December 15, 2009.

Diamond, Larry. 1988. Class, Ethnicity, and Democracy in Nigeria: The Failure of the First Republic. Syracuse, N.Y.: Syracuse University Press.

Dionne, Kim Yi, Kris L. Inman, and Gabriella R. Montinola. 2014. "Another Resource Curse? The Impact of Remittances on Political Participation.” Afrobarometer Working Paper no. 145. At www.afrobarometer.org, accessed July 20, 2014.

Dunning, Thad. 2008. Crude Democracy: Natural Resource Wealth and Political Regimes. New York, N.Y.: Cambridge University Press.

Dunning, Thad, and Lauren Harrison. 2010. "Cross-cutting Cleavages and Ethnic Voting: An Experimental Study of Cousinage in Mali." American Political Science Review 104, no. 1: 21-39.

Esteban, Joan, and Debraj Ray. 2011. "A Model of Ethnic Conflict.” Journal of the European Economic Association 9, no. 3: 496-521.

Fenwick, Rudy 1981. "Social Change and Ethnic Nationalism: An Historical Analysis of the Separatist Movement in Quebec." Comparative Studies in Society and History 3, no. 2: 196-216.

Figueroa, Adolfo, and Manuel Barrón. 2005. "Inequality, Ethnicity, and Social Disorder in Peru." CRISE Working Paper no. 8. Oxford, UK: University of Oxford Centre for Research on Inequality, Human Security, and Ethnicity.

Franck, Raphaël, and Ilia Rainer. 2012. "Does the Leader's Ethnicity Matter? Ethnic Favoritism, Education, and Health in Sub-Saharan Africa." American Political Science Review 106, no. 2: 294-325. 
Gates, Scott. 2002. "Recruitment and Allegiance: The Microfoundations of Rebellion." Journal of Conflict Resolution 46, no. 1: 111-30.

Gee, Ellen M., Karen M. Kobayashi, and Steven G. Prus. 2007. "Ethnic Inequality in Canada: Economic and Health Dimensions." In David A. Green and Jonathan R. Kesselman, eds., Dimensions of Inequality in Canada. Vancouver, Canada: UBC Press.

Goemans, Hein E., Kristian Skrede Gleditsch, and Giacomo Chiozza. 2009. "Archigos: A Data Set on Leaders 1875-2004, ver. 2.9." At http://www.roch ester.edu/college/faculty/hgoemans/data.htm, accessed June 20, 2014.

Green, David A., and Jonathan R. Kesselman, eds. 2007. Dimensions of Inequality in Canada. Vancouver, Canada: UBC Press.

Gubler, Joshua R., and Joel Sawat Selway. 2012. "Horizontal Inequality, Crosscutting Cleavages and Civil War." Journal of Conflict Resolution 56, no. 2: 206-32.

Haber, Stephen, and Victor Menaldo. 2011. "Do Natural Resources Fuel Authoritarianism? A Reappraisal of the Resource Curse." American Political Science Review 105, no. 1: 1-26.

Haggard, Stephan, and Robert R. Kaufman. 2012. "Inequality and Regime Change: Democratic Transitions and the Stability of Democratic Rule." American Political Science Review 106, no. 3: 495-516.

Haggard, Stephan, Robert R. Kaufman, and Terence K. Teo. 2012. "Distributive Conflict and Regime Change: A Qualitative Data Set.” At http://fas-polisci .rutgers.edu/kaufman/HKT_Dataset_v1.1.pdf, accessed June 20, 2014.

Honaker, James, Gary King, and Matthew Blackwell. 2011. "Amelia II: A Program for Missing Data." Journal of Statistical Software 45, no. 7: 1-47.

Horowitz, Donald L. 1985. Ethnic Groups in Conflict. Berkeley, Calif.: University of California Press.

Houle, Christian. 2009. "Inequality and Democracy: Why Inequality Harms Consolidation but Does Not Affect Democratization." World Politics 61, no. 4 (October): 589-622.

- Forthcoming. "Does Inequality Harm Economic Development and Democracy? Accounting for Missing Values, Non-Comparable Observations and Endogeneity." In Carol Lancaster and Nicolas van de Walle, eds., Oxford Handbook of the Politics of Development. Oxford, UK: Oxford University

\footnotetext{
Press. 15000106.
}

International Social Survey Program. At www.issp.org, accessed June 20, 2014.

Krishna, Anirudh, ed. 2008. Poverty, Participation and Democracy: A Global Perspective. New York, N.Y.: Cambridge University Press.

Kuhn, Patrick, and Nils B. Weidmann. 2014. "Unequal We Fight: Between- and Within-Group Inequality and Ethnic Civil War." Paper presented at the annual meeting of the Midwest Political Science Association, Chicago, April 3-6. At https://www.princeton.edu/politics/about/file-repository/public/Kuhn Weidmann_PrincetonIRTalk.pdf, assessed June 202014.

Laitin, David. 1986. Hegemony and Culture: Politics and Religious Change among the Yoruba. Chicago, I1l.: University of Chicago Press.

Lancaster, Carol J., and Nicolas van de Walle, eds. Forthcoming. Oxford Handbook of the Politics of Development. Oxford, UK: Oxford University Press. 
Langer, Arnim, Abdul Raufu Mustapha, and Frances Stewart. 2007. "Horizontal Inequalities in Nigeria, Ghana and Côte D'Ivoire: Issues and Policies.” CRISE Working Paper no. 45. Oxford, UK: University of Oxford Centre for Research on Inequality, Human Security and Ethnicity.

Langlois, Simon. 2002. "Empirical Studies on Social Stratification in Quebec and Canada." In Yannick Lemel, and Heinz-Herbert Noll, eds., Changing Structures of Inequality: A Comparative Perspective. Montreal, Canada: McGillQueen's University Press.

Latinobarometer. At www.latinobarometro.org, accessed June 20, 2014.

Lemel, Yannick, and Heinz-Herbert Noll, eds. 2002. Changing Structures of Inequality: A Comparative Perspective. Montreal, Canada: McGill-Queen's University Press.

Lin, Tse-Min, and Baohui Zhang. 1998. "Cross-Cutting Issues and the Consolidation of Democracy in Taiwan." Democratization 5, no. 4: 118-43.

Lipset, Seymour Martin. 1960. Political Man: The Social Bases of Politics. New York, N.Y.: Doubleday \& Company.

Lipset, Seymour Martin, and Stein Rokkan, eds. 1967. Party Systems and Voter Alignments. New York, N.Y.: Free Press.

Meltzer, Allen H., and Scott F. Richard. 1981. "A Rational Theory of the Size of Government.” Journal of Political Economy 89, no. 5: 914-27.

Muller, Edward N. 1988. "Democracy, Economic Development, and Income Inequality." American Sociological Review 53, no. 1: 50-68.

Nattrass, Nicoli, and Jeremy Seekings. 2001. "Democracy and Distribution in Highly Unequal Economies: The Case of South Africa." Journal of Modern African Studies 39, no. 3: 471-98.

Østby, Gudrun. 2008. "Polarization, Horizontal Inequalities and Violent Civil Conflict." Journal of Peace Research 45, no. 2: 143-62.

Østby, Gudrun, Ragnhild Nordås, and Jan Ketil Rød. 2009. "Regional Inequalities and Civil Conflict in Sub-Saharan Africa." International Studies Quarterly 53, no. 2: 301-24.

Papaionannou, Elias, and Gregorios Siourounis. 2008. "Economic and Social Factors Driving the Third Wave of Democratization." Journal of Comparative Economics 36: 365-87.

Powell, Jonathan M., and Clayton L. Thyne. 2011. "Global Instances of Coups from 1950-2010: A New Dataset." Journal of Peace Research 48, no. 2: 249-59.

Przeworski, Adam. 1991. Democracy and the Market: Political and Economic Reforms in Eastern Europe and Latin America. New York, N.Y.: Cambridge University Press.

Przeworski, Adam, Michael E. Alvarez, José Antonio Cheibub, and Fernando Limongi. 2000. Democracy and Development: Political Institutions and Well-Being in the World, 1950-1990. New York, N.Y.: Cambridge University Press.

Rabushka, Alvin, and Kenneth A. Shepsle. 1972. Politics in Plural Societies: A Theory of Democratic Instability. Columbus, Ohio: Charles E. Merrill Publishing Co.

Rae, Douglas W., and Michael Taylor. 1970. The Analysis of Political Cleavages. New Haven, Conn.: Yale University Press.

Roessler, Philip. 2011. "The Enemy Within: Personal Rule, Coups, and Civil War in Africa." World Politics 63, no. 2 (April): 300-46. 
Rokkan, Stein. 1967. "Geography, Religion, and Social Class: Cross-Cutting Cleavages in Norwegian Politics." In Seymour Martin Lipset and Stein Rokkan, eds., Party Systems and Voter Alignments. New York, N.Y.: Free Press.

Ross, Edward Alsworth. 1920. The Principles of Sociology. New York, N.Y.: Century Co.: 164-65.

Sambanis, Nicolas, and Branko Milanovic. 2011. "Explaining the Demand for Sovereignty." Policy Research Working Paper Series no. 5888. Washington, D.C.: World Bank. At http://papers.ssrn.com/sol3/papers.cfm?abstract_ id=1965919, accessed July 202014.

Selway, Joel Sawat. 2011. "Cross-Cuttingness, Cleavage Structures and Civil War Onset." British Journal of Political Science 41, no. 1: 111-38.

Seul, Jeffrey R. 1999. "Ours is the Way of God: Religion, Identity, and Intergroup Conflict." Journal of Peace Research 36, no. 5: 553-69.

Simmel, Georg. 1908. Soziologie. Leipzig, Germany: Duncker \& Humblot.

Slater, Dan, Benjamin Smith, and Gautam Nair. 2014. "Economic Origins of Democratic Breakdown? The Redistributive Model and the Postcolonial State." Perspectives on Politics 12, no. 2: 353-74.

Stewart, Frances. 2000. "Crisis Prevention: Tackling Horizontal Inequalities." Oxford Development Studies 28, no. 3: 245-62.

- 2002. "Horizontal Inequalities: A Neglected Dimension of Development." Queen Elizabeth House Working Paper Series no. 81. Oxford, UK: University of Oxford. At https://srilankandiasporablog.files.wordpress.com /2008/07/workingpaper1.pdf, accessed July 252014.

lence in Multiethnic Societies. New York, N.Y.: Palgrave Macmillan.

Themnér, Lotta, and Peter Wallensteen. 2014. "Armed Conflict, 1946-2013." Journal of Peace Research 51, no. 4: 525-36.

Thorp, Rosemary, and Maritza Paredes. 2010. Ethnicity and the Persistence of Inequality: The Case of Peru (Conflict, Inequality and Ethnicity). New York, N.Y.: Palgrave Macmillan.

Timmons, Jeffrey F. 2010. "Does Democracy Reduce Economic Inequality?” British Journal of Political Science 40, no. 4: 741-57.

Treisman, Daniel. Forthcoming. "Income, Democracy, and Leader Turnover." American Journal of Political Science.

Truman, David B. 1951. The Governmental Process: Political Interests and Public Opinion. New York, N.Y.: Alfred A. Knopf.

Verba, Sidney. 1965. "Organizational Membership and Democratic Consensus." Journal of Politics 27, no. 3: 467-97.

Wimmer, Andreas, Lars-Erik Cederman, and Brian Min. 2009. "Ethnic Power Relations Dataset.” At http://hdl.handle.net/1902.1/11796, accessed December 15, 2009.

World Values Survey. At www.worldvaluessurvey.org, accessed 20 June, 2014. 